University of Florida Levin College of Law

UF Law Scholarship Repository

UF Law Faculty Publications

Faculty Scholarship

2019

Comparative Warranty Law: Case of Planned Obsolescence

Stefan Wrbka

Larry A. DiMatteo

University of Florida Levin College of Law, dimatteo@ufl.edu

Follow this and additional works at: https://scholarship.law.ufl.edu/facultypub

Part of the Consumer Protection Law Commons

Recommended Citation

Stefan Wrbka \& Larry A. DiMatteo, Comparative Warranty Law: Case of Planned Obsolescence, 21 U. Pa. J. Bus. L. 907 (2019)

This Article is brought to you for free and open access by the Faculty Scholarship at UF Law Scholarship Repository. It has been accepted for inclusion in UF Law Faculty Publications by an authorized administrator of UF Law Scholarship Repository. For more information, please contact kaleita@law.ufl.edu. 


\title{
COMPARATIVE WARRANTY LAW: CASE OF PlanNed ObSOLESCENCE
}

\author{
Stefan Wrbka* \\ Larry A. DiMatteo**
}

\begin{abstract}
The cause of our present stagnation is that the supply line or arteries furnishing the needs of the country are clogged with obsolete, outworn and outmoded machinery, buildings and commodities of all kinds. These are obstructing the avenues of commerce and industry and are preventing new products from coming through. There is little demand for new goods when people make their old and worn-out things do, by keeping them longer than they should. ${ }^{1}$
\end{abstract}

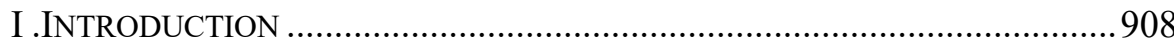

A. Problem of Planned Obsolescence ........................................911

B. Planned Obsolescence in Historical Context...........................913

II. PlANNED OBSOLESCENCE IN THE CONTEXT OF WARRANTY LAW:

COMPARATIVE PERSPECTIVES ....................................................916

III. WARRANTY LAW AS A REGULATORY REGIME FOR PLANNED

OBSOLESCENCE.

* Unit Head and Academic Coordinator, Business Law at the University of Applied Sciences for Management and Communication, Vienna, Mag. iur., University of Vienna; LL.M. Kyushu University; Ph.D. (Dr. iur.) University of Vienna.

** Huber Professor of Contract Law, University of Florida, J.D. Cornell; LL.M. Harvard University; Ph.D. Monash University. The authors would like to thank the following contributors for their invaluable feedback on country laws for this the study: Tharani Balachandran, Lei Chen, Camilla Crea, Samatha David, Mateja Durovic, Charl Engelbrecht, Suren Gomtsyan, Jakob S. Hedegaard, Thang Hoang, Antonios Karaiskos, Jae J. Kim, Jonas Knetsch, Hava Kossoumova, James Kwan, Hue Le, Peter Lee, João Mateus Thomé de Souza Lima, Lukas Lüthi, Andrea Martinez, Jerry Mayaba, Vidisha Nandi, Veronika Pavlovskaya, Phong Pham, Anastasiia Popova, Vlera Rexha, Luana Gonçalves Salignac, Pankaj Singla, Hiroo Sono, Natalya Spuling, Konstantions Stylianou, Alexandre Talbot, David Tilt, Navchaa Tseveen, Evgenia Volkova, Ye Xin, Zinian Zhang, and Agata Zwolankiewicz.

1. Bernard London, Ending the Depression Through Planned Obsolescence (1932). 
A. General Remarks and Findings.........................................919

B. United States ................................................................. 921

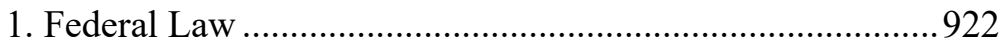

2. State Law ................................................................... 923

C. European Union ................................................................937

1. Situation at the Pan-EU Level........................................937

2. "Passive" Member States ................................................. 941

3. "Active" Member States .................................................. 944

D. Other Jurisdictions ................................................................ 949

1. Availability of Warranty Law .........................................949

2. Liability Under Warranty Law......................................952

3. Possible Remedies ...................................................... 954

4. Time Factor .............................................................. 958

IV. FiXING THE PROBLEM OF PlANNED OBSOLESCENCE: POSSIBLE

WAYS FORWARD FROM A WARRANTY LAW PERSPECTIVE............964

A. Extending Mandatory Product Warranty Periods....................965

1. Tolling.............................................................................. 965

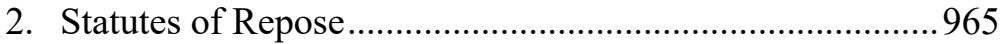

B. Recognizing Planned Obsolescence as a Latent Defect ..........966

1. Limitation Period Begins at Time Buyer Knew (or

Should Have Known) of Defect........................................996

2. State of the Art: Existence Versus as Practiced................... 968

3. Defense: Disclosure of Durability ....................................969

C. Issues Relating to EWSCs ................................................970

D. Implied Warranty of Durability ............................................971

E. Remedies: Duty to Repair................................................972

1. Prioritizing Repair over Replacement.............................972

2. Right to Self-Repair ........................................................ 974

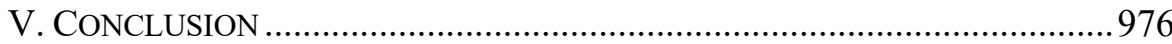

\section{INTRODUCTION}

Bernard London's call for shorter product lifecycles, voiced in his controversial 1932 commentary "Ending the Depression Through Planned Obsolescence,"2 came less than a decade after the first cases of planned obsolescence - the phenomenon of deliberately shortening the durability of

2. $I d$. 
products, had been unmasked. ${ }^{3}$ Roughly ninety years have passed since the early beginnings of the planned obsolescence debate. While the first decades primarily focused on economic, environmental, technological, and socio-political topics, more recent years have seen a stronger linkage to legal issues and legislative considerations. In the European Union ("EU") in particular, these trends have reached a considerable magnitude. In late 2013, for example, the European Economic and Social Committee ("EESC") $)^{4}$ addressed planned obsolescence in depth and criticized its abusive use. ${ }^{5}$ A core environmental protection concern is the sustainability of natural resources including the diminishment of waste. The need for sustainability of resources has been universally recognized as a common goal of humanity. ${ }^{6}$ Premature product obsolescence directly relates to this goal. The EESC took the opportunity to comment on a number of legal tools that it believes would be helpful in solving the problem of planned obsolescence. One suggested avenue of recourse would be the expansion of existing warranty law. Previously, the European Commission in 2011 noted that warranty law might be the most logical instrument to be used by purchasers to seek a remedy for products failing due to planned obsolescence. ${ }^{7}$ This article explores the potential and usability of warranty law to this end.

In the United States ("U.S."), there is little legal scholarship on the issue of planned obsolescence. Consumers must rely on ratings of durability provided by non-governmental entities. ${ }^{8}$ If a product's durability

3. See infra Part I.B (providing greater detail on the history of planned obsolescence).

4. The EESC is an influential consultative body in the EU with representatives from and ties to a variety of interest groups that include industries, as well as consumers.

5. See, e.g., European Econ. \& Soc. Comm., Towards More Sustainable Consumption: Industrial Product Lifetimes and Restoring Trust Through Consumer Information (Oct. 17, 2013), https://www.eesc.europa.eu/en/our-work/opinions-information-reports/opinions/towa rds-more-sustainable-consumption-industrial-product-lifetimes-and-restoring-trust-throughconsumer-information [https://perma.cc/CK7R-6NYU] (detailing allegations among the voiced concerns: negative influences on the environment, public health and the financial stability of civil society).

6. See Principle Eight: Environment, United Nations Global Compact, https://www.unglobalcompact.org/what-is-gc/mission/principles/principle-8 [https://perma.c c/R2AC-GD8F] (listing steps towards economic responsibility, including the development of sustainability targets and the establishment of a sustainable production and consumption program).

7. See infra Part II (discussing the relationship between planned obsolescence and warranty law).

8. See, e.g., About Us, CONSUMER REPORTS, http://www.consumerreports.org/cro/abou t-us/what-we-do/index.htm [https://perma.cc/3JX3-YWPR] (last visited Mar. 31, 2019) (demonstrating that consumers will pay for access to consumer reports from an 
fails to meet the reasonable expectations of the purchaser, the purchaser is left with little legal recourse. The duration of the warranty period or extended warranty period is often less than the reasonable expectation of durability of the ordinary purchaser. This is because products are engineered to fail prematurely ${ }^{9}$ but after the expiration of the warranty periods, which may be as little as one year as provided for the American Uniform Commercial Code ("UCC"). ${ }^{10}$ In the sale of durable goods, such as automobiles, kitchen appliances, and certain electronic devices, such a limitation period is grossly inadequate to prevent planned obsolescence and its abuse by manufacturers and sellers.

This article starts from the premise that many products are engineered to fail (planned obsolescence). Importantly, scarce resources are inefficiently allocated to producing replacements for previously sold products with shortened lifespans, which is contrary to the sustainability goals expressed by companies and countries alike.

The purpose of the current undertaking is to explore the use of warranty law to remedy cases of planned obsolescence. Such an approach should be measured on two parameters: providing an adequate remedial structure for purchasers of products and deterring manufacturers from producing goods with unnecessarily short lifespans. It should be the goal of an expanded warranty regime to incentivize producers to manufacture goods with longer lifespans or greater durability.

One suggestion is to expand implied warranty law to include an implied warranty of durability or sustainability. ${ }^{11}$ Such a warranty would serve numerous societal interests, such as the reduction of industrial waste and greater sustainability of resources. The issue of planned obsolescence is a problem affecting numerous interest groups from the micro to macro levels. At the consumer level, there is scarce protection against the selling of products, as well as extended warranty or service contracts, calculated by manufacturers to expire before the lifespan of the product. At the macro

"independent, nonprofit member organization that works side by side with consumers for truth, transparency, and fairness in the marketplace").

9. "Engineered to fail prematurely" is the concept that, with little or no additional costs, the lifespan of a product may be extended. The economic incentives for producing less-durable products are to advance future sales of replacement products or to sell replacement parts.

10. U.C.C. § 2-725 (AM. LAw InST. \& UnIF. LAW Comm’N 1977).

11. E.g. Christine Hottinger, For an Implied Warranty of Sustainability: Come Mr. Tallyman, Tally My Banana's Environmental Impact, 26 Geo. INT'L ENVTL. L. ReV. 303 (2014) (making the case for an implied warranty of sustainability in order to increase the sustainability of banana production). 
level, the battle against environmental pollution and climate change requires that natural resources be used efficiently. This includes the production of goods that have sufficient durability. In addition, the durability of products should be enhanced by changes in the law that would recognize repair as the primary remedy instead of replacement.

This article takes a broad comparative analysis by reviewing existing laws in more than fifty countries. This comparative review will show that most countries are lacking sufficient regulations that require manufacturers to produce reasonably durable products. The review also provides an overview of the challenges warranty law faces in regulating planned obsolescence. It is from there that a framework can be created of new rules - inside and outside of warranty law - to deal with the vitally important problem of the waste of natural resources, environmental pollution, and global sustainability.

The current part will briefly introduce and discuss the problem of planned obsolescence and place the current state of the problem in a historical context. Part II explores the approach of dealing with the problem of planned obsolescence within the context of warranty law. Part III provides a comparative analysis of the intersection of warranty law and planned obsolescence in the U.S. and the European Union ("EU"), as well as individual countries within Europe and elsewhere. The analysis separates countries into "passive" and "active" regarding the regulation of planned obsolescence. Based upon the findings of Part III, Part IV analyzes the issues relating to the expanded use of warranty law to regulate planned obsolescence. It looks at a broad variety of national laws to the extent warranty law is available, whether it can be used to regulate planned obsolescence, the appropriate remedial structure for cases of planned obsolescence, and the problem of temporal constraints due to the misalignment of warranty periods and the discovery of planned obsolescence. We will conclude with a summary of key findings and a short remark on the possible future.

\section{A. Problem of Planned Obsolescence}

Before we start with our legal analysis, a definition of the term "planned obsolescence" is offered. In a very simplified way, one can note that the term refers to any manufacturing strategy that prematurely ends the use of a product by a purchaser and, thus, requires a replacement purchase 
of the same or similar product. ${ }^{12}$

One of the first attempts to divide the phenomenon into different categories was taken by Vance Packard in his 1960 book The Waste Makers. He introduced three basic groups or types of obsolescence: "obsolescence of desirability," "obsolescence of function," and "obsolescence of quality."13 These three categories are the three pillars of planned obsolescence. First, obsolescence of desirability discusses the development from a predominantly psychological-persuasive perspective. Its focus is on the question of how to make users purchase new goods without applying any technical barriers or introducing new technical features. The decision by General Motors to update the design of its cars at short intervals to outcompete its main competitor Ford Motor Company in the early 1920s is one of the first reported cases of a strategy aimed at the obsolescence of desirability. ${ }^{14}$

Second, the obsolescence of function is understood to boost product sales by introducing (allegedly) advanced technical features that would prompt users to replace a product with its successor. The constant production of new generations of smart phones provides a modern-day example of this type of obsolescence. Here, producers introduce new, (more or less) innovative features that (tacitly or explicitly) embody better or superior follow-up products. The obsolescence of desirability and the obsolescence of function relate to the voluntary end of product use rather than a forced end due to a lack of durability.

Third, obsolescence of quality adds a "product immanent force" perspective. In this scenario, it is not the user's free choice to replace the product. The reason for replacement is that the product does not function or does not perform in a functionally efficient way and likely repairs are no longer cost efficient. As will be seen later in the article, it is particularly

12. Alternative definitions include the "phenomenon of shortening the lifecycle of goods." Mark Fenwick \& Stefan WrbKa, International Business Law: EMERging Fields of Regulation 56 (2018); see Stefan Wrbka, Warranty Law in Cases of Planned Obsolescence - The Austrian Situation, EuCML 67, 67 (2017) (defining planned obsolescence as "strategies and techniques of premature product aging applied by producers and sellers for the purpose of making end users replace old products with new ones faster than they ordinarily would by shortening the time of their use"); see also MARK FENWICK \& SteFAn WrbKa, InTERnAtional Business LAw: EMERging Fields of Regulation 56 (2018) (referring to planned obsolescence as "strategies and techniques of premature product aging that would motivate, or even force, buyers to purchase new goods more frequently").

13. Vance Packard, The Waste Makers 66-67 (1960).

14. Giles Slade, Made to Break: Technology and Obsolescence in America 2955 (2006). 
this third category that is the basis for possible warranty claims. Hence, the remainder of this article will, unless stated differently, refer to this third understanding of planned obsolescence.

\section{B. Planned Obsolescence in Historical Context}

The emergence of the planned obsolescence of quality debate can be linked to the Phoebus cartel of the mid-1920s, when manufacturers colluded to limit the life of incandescent light bulbs. ${ }^{15}$ Until the late 1950s, planned obsolescence discussions were (in principle) limited to the U.S. market. Early debates were characterized by economic and socio-political arguments. ${ }^{16}$ The topic began to gain greater attention when Packard's obsolescence publications were translated into non-English languages and sold abroad. ${ }^{17}$ In terms of the focus of foreign debates, there was, however,

15. See Jana Valant, European Parliament, Planned Obsolescence: Exploring THE ISSUE 3 (2016), www.europarl.europa.eu/RegData/etudes/BRIE/2016/581999/EPRSBRI (2016)581999_EN.pdf [https://perma.cc/JCV8-A9JJ] (showing that "[o]ne of the last remaining examples of the old bulb, the Centennial Light Bulb, manufactured by the Shelby Electric Company and installed in 1901, still continues to function 24 hours a day in 2016"). See, e.g., The Monopolies and Restrictive Practices Commission, Report on the SUPPLY OF ELECTRIC LAMPS, 1951, HC 287, at 126 (UK), https://assets.publishing.service.go v.uk/government/uploads/system/uploads/attachment_data/file/235313/0287.pdf [https://per ma.cc/H6GQ-SYGQ] (showing that the worldwide leading light-bulb producers agreed on limiting the durability of light bulbs to a maximum of 1,000 operational hours - despite the fact that from a purely technical perspective it was to exceed this lifetime by far). For further comments on a variety of other early planned obsolescence cases, see SLADE, supra note 14 (providing an overview of twentieth century history through the lens of planned obsolescence); JÜrgen Reuß \& Cosima DanNoritzer, KaUfen für Die Müllhalde: Das PRINZIP DER GEPLANTEN OBSOLESZENZ (2013) (describing how economies have flourished from planned obsolescence due to cheap production and use of raw materials).

16. See London, supra note 1 (arguing that planned obsolescence has a beneficial economic impact). Contra PACKARD, supra note 13 (asserting three groups of obsolescence); Vance Packard, The Hidden Persuaders (1957) (exploring the psychological techniques advertisers use to persuade consumers to make purchases). See Burkhardt Röper, Gibt es geplanten Verschleiß?, in FESTSCHRIFT FÜr THEOdOR PÜTZ 261 (Ernst Dürr et al. eds., 1975) (discussing whether manufacturers actively choose planned obsolescence); BURKHARDT RÖPER, GIBT ES GEPLANTEN VERSCHLEISS? - UNTERSUCHUNGEN ZUR OBSOLESZENZTHESE (1976) (investigating planned obsolescence by manufacturers); Karl-Heinz Hillmann, Kritische Stellungnahme zum Gutachten von Burkhart Röper über das Problem “Gibt es geplanten Verschleiß?”, ZEITSCHRIFT FÜR VERBRAUCHERPOLITIK 48 (1977) (critically responding to Röper's investigations into planned obsolescence); Burkhardt Röper, Gibt es geplanten Verschleiss? Eine Antwort auf die Kritik von Hillmann, ZEITSCHRIFT FÜR VERBRAUCHERPOLITIK 185 (1977) (providing an "early" intense dispute in the German language).

17. PACKARD, supra note 13. Packard's The Hidden Persuaders was first published in 
not much difference from their U.S. counterparts.

Things started to change, and the planned obsolescence debate gained momentum with the rise of the environmental movement in the 1970s. Looking at European debates in particular, one can notice that in more recent decades, environmental concerns over unsustainable production and the utility of products have dominated the critical literature on planned obsolescence and respective policy discussions both at national and pan-EU levels. ${ }^{18}$ Since the early 2000 s, the EU legislature has been intensifying its efforts in passing environmental legislation that (in the view of EU policymakers) ${ }^{19}$ has the potential to address the problem of planned obsolescence. Prominent examples include the Ecodesign Directive, ${ }^{20}$ the Energy Labelling Directive, ${ }^{21}$ the Waste Electrical and Electronic Equipment Directive, ${ }^{22}$ and the Waste Framework Directive, ${ }^{23}$ which all support sustainable production and consumption.

At the EU Member State level, several initiatives have addressed the issue more directly. The success of these national efforts, however, differs considerably. In some Member States, projects have not gone beyond mere policy debates. Examples can be found in Austria and Germany, both of

the German language in 1957 (VAnce PACKARD, DiE GeHeIMen Verführer (1957)); Packard's The Waste Makers was first published in the German language in 1961 (VANCE PACKARD, Die GROßE VERSChWENDUNG (1961)).

18. See, e.g., Commission to the European Parliament and the Council, Building the Single Market for Green Products: Facilitating Better Information on the Environmental Performance of Products and Organisations, COM (2013), 196 final (Apr. 9, 2013) (providing incentives for consumers to choose more resource-efficient and environmentally friendly products); SidDharth Prakash ET AL., EINfluss DER NutzungSDAuER VON PRODUKTEN AUF IHRE UMWELTWIRKUNG: SCHAFFUNG EINER INFORMATIONSGRUNDLAGE UND ENTWICKLUNG VON STRATEGIEN GEGEN „OBSOLESZENZ“ (2015), https://www.umweltbundes amt.de/sites/default/files/medien/378/publikationen/texte102015einflussdernutzungsdauervo nproduktenaufihreumweltobsoleszenz17.3.2015.pdf [https://perma.cc/HT79-2L97] (creating an information base and strategies against planned obsolescence); STEFAN SCHRIDDE, Murks? NeIn DANKe! WAS WIR TUN KÖNNEN, DAMIT DIE Dinge BeSSER WERDEN (2014) (containing stories about products with planned obsolescence so as to teach readers about the existence of this phenomenon).

19. European Econ. \& Soc. Comm., supra note 5, paras. 1.8, 1.12, at 2-3.

20. Council Directive 2009/125/EC, 2009 O.J. (L 285) 10 (establishing a framework for the setting of eco-design requirements for energy-related products).

21. Council Directive 2010/30/EU, 2010 O.J. (L 153) 1 (promoting labelling and standard product information of the consumption of energy and other resources by energyrelated products).

22. Council Directive 2002/96/EC, 2003 O.J. (L 37) 24 (providing measures to address electrical and electronic equipment waste).

23. Council Directive 2008/98/EC, 2008 O.J. (L 312) 3 (creating additional measures for waste management). 
which have been active in mandating pertinent studies and analyses, but thus far have failed to implement concrete rules or regulations. ${ }^{24}$ Germany is also among those Member States that have attempted unsuccessfully to pass specific laws to support sustainable production. Legislative drafts found in these countries include a variety of mechanisms that range from prescribing mandatory minimum lifetimes for certain products to softer approaches such as broadening the use of lifespan labeling. ${ }^{25}$

The only successful example of the enactment of specific legislation on planned obsolescence is found in France. In 2015, driven by environmental concerns, ${ }^{26}$ the French legislature amended the French

24. AK WIEN, GEKAUFT UND SCHON KAPUTT. LEBEN IN EINER WEGWERFGESELLSCHAFT? (2013), www.arbeiterkammer.at/infopool/wien/Tagungsband_Obsoleszenz.pdf [https://perm a.cc/V5JP-VT9K]. See also Austrian Standards Inst., GÜTEZEICHEN FÜR LANGLEBIGE, REPARATURFREUNDLICH KONSTRUIERTE ELEKTRISCHE UND ELEKTRONISCHE GERÄTE (2014) (recommending the introduction of a "Label of Excellence" for durable, repair-friendly designed electrical and electronic appliances to be voluntarily used by producers to identify sustainably produced goods); ARGE REGIO, GePlante OBSOleszenz: GUTACHTEN IM AUFTRAG DER BUNDESTAGSFRAKTION (2013), https://www.gruene-bundestag.de/fileadmin/m edia/gruenebundestag_de/themen_az/umwelt/PDF/Studie-Obsoleszenz-aktuell.pdf [https://p erma.cc/B5ER-LFJZ] (presenting a heavily debated study that was mandated by the German Green Party and led to a second, broader study by the German Federal Environment Agency, published in 2016 (UMweltbundesAmt, EINFLuSS DER NUTZUNGSDAUER VON PRODUKTEN AUF IHRE UMWELTWIRKUNG: SCHAFFUNG EINER INFORMATIONSGRUNDLAGE UND ENTWICKLUNG VON STRATEGIEN GEGEN „OBSOLESZENZ“ (2016))).

25. Relevant examples can be found in Belgium, including lifespan labeling strategies and explicit references to planned obsolescence as an example of unfair commercial practices. See, e.g., Proposition de résolution en vue de lutter contre l'obsolescence programmée des produits liés à l'énergie, 5-1251/1 [Proposal for a Resolution to Combat the Planned Obsolescence of Energy-Related Products], Senat DE BeLgique (Oct. 7, 2011), www.senate.be/www/?MIval=/publications/viewPub.html\&COLL $=\mathrm{S} \& L E G=5 \& N R=1251 \&$ VOLGNR=1\&LANG=fr [https://perma.cc/M7E5-DZXS] (seeking to limit planned obsolescence due to the financial harm brought to consumers). See Regierungsentwurf [Cabinet Draft], Deutscher BundestaG: DrucKSAChen [BT] 17/13096, http://dip21.bunde stag.de/dip21/btd/17/130/1713096.pdf [https://perma.cc/CZZ5-6TWL] (Ger.) (discussing minimum durability requirements in Germany). See also Regierungsentwurf [Cabinet Draft], Deutscher BundestaG: DRuCKSACHen [BT] 17/13917, http://dipbt.bundestag.de/d oc/btd/17/139/1713917.pdf [https://perma.cc/6MY8-7K7G] (Ger.) (describing the need for regulation on planned obsolescence). See Disposizioni per il contrasto dell'obsolescenza programmata dei beni di consumo [Draft Provisions on Fighting Planned Obsolescence of Consumer Goods], OPENPARLAMENTO (Nov. 4, 2015), parlamento17.openpolis.it/atto/do cumento/id/163692 [https://perma.cc/522W-Z3BT] (focusing on the availability of spare parts in Italy).

26. A Peine Votée, Déjà Enterrée?, Universite Toulouse 1 Capitole (Mar. 6, 2015), magazine.ut-capitole.fr/a-peine-votee-deja-enterree--506206.kjsp [https://perma.cc/H36ECJ3X]; L'Avancée du Sénat: Vers un Matériel Durable?, LetTre des JuRISTES DE L'ENVIRONNEMENT (Mar. 3, 2015), www.juristes-environnement.com/articledetail.php?id=1 
Consumer Code (Code de la Consommation) and introduced a specifically crafted penal provision on planned obsolescence. Article L213-4-1 (I) and (II) read as follows: "Planned obsolescence is defined as any measure with the intent to conceptually reduce the operating life of a good for economic considerations," and "[i]t is punishable with two years of imprisonment and a fine of EUR 300,000."27 In 2016, the regime was slightly updated and moved to Articles L441-2 (definition of planned obsolescence) and L454-6 (sanctions). The new definition of planned obsolescence is as follows: "The practice of planned obsolescence is the prohibited use of techniques by which the person who places a product on the market aims to deliberately reduce the lifespan of the product to increase its replacement rate." ${ }^{28}$ The sanctions include a possible increase of the fine to a maximum of " $5 \%$ of the average annual turnover, calculated based on the last three annual turnover numbers known at the time of the offence." ${ }^{29}$ Although several investigations have been initiated since the introduction of these rules, no judgment has yet been issued..$^{30}$

Despite these trends and efforts, legislators and other actors around the world have remained relatively passive when it comes to examining the full potential of warranty law in the obsolescence context. The vast majority of stakeholders, however, have not considered utilizing warranty law. Nonetheless, warranty law may be suitable to address the topic of planned obsolescence. This article provides an analysis of how warranty law can be used to regulate the problem of planned obsolescence in selected jurisdictions. Before presenting the finding of the comparative analysis of warranty law, the next Part places planned obsolescence in the context of warranty law and provides a brief discussion of the relationship between the two.

\section{PlaNNED OBSOLESCENCE IN THE CONTEXT OF WARRANTY LAW: COMPARATIVE PERSPECTIVES}

There are a number of areas of law that can be considered to regulate the problem of planned obsolescence. The most popular or obvious ones

885 [https://perma.cc/252C-5F6K].

27. Code de la Consommation [Consumer Code] art. L213-4-1(I), (II) (Fr.) (translation by Stefan Wrbka).

28. Code de la Consommation [Consumer Code] art. L441-2 (Fr.).

29. Code de la Consommation [CONSUmer Code] art. L454-6 (Fr.).

30. Noteworthy investigations include possible infringements by Epson, Canon, Brother and Hewlett Packard (printers) and Apple (iPhones) - information provided by Alexandre Talbot on December 2, 2018 (on file with authors). 
include unfair competition (antitrust) and environmental laws. Other narrower areas of law that may be applicable are the laws of unfair commercial practices or consumer protection laws. ${ }^{31}$ These laws may be applicable in cases of misrepresentation or fraud, namely, when producers claim products are of supreme quality, which at best is misleading or can be interpreted as an intentional misrepresentation. None of these tools, however, is likely to fully address the specific issue of planned obsolescence because they fail to directly focus on the purchaser's side. Other anti-planned obsolescence mechanisms involving numerous stakeholders will be needed to make a sufficient impact. The existing law that seems best suited for the task is warranty law. This was noted in the 2013 EESC opinion article on planned obsolescence ${ }^{32}$ and the European Commission's survey of more precise evidence on the topic. ${ }^{33}$ The European Commission expressed the view that warranty law is one of the key tools to counteract planned obsolescence. Arguably the strongest and most explicit claim was made in July 2011, when the European Commission issued the following statement:

The Commission considers that 'planned obsolescence' ... can have negative impacts on consumers' interests, on the environment, and on fair competition. European legislation provides means to combat such practices. Firstly, Directive 99/44/EC on the sale of consumer goods and associated

31. See, e.g., European Comm'n, Answer Given by Mr. Tajani on Behalf of the Commission, European PARLiament (Aug. 1, 2013), www.europarl.europa.eu/sides/getAll Answers.do? reference=E-2013-006339\&language=EN [https://perma.cc/9L25-7NMT] (noting that the Commission evaluates the durability of consumer products with the laws of unfair commercial practice and consumer protection).

32. European Econ. \& Soc. Comm., supra note 5, para. 1.9, at 3 (stating that "[t]he EESC suggests that warranties should include a minimum operating period, during which the cost of any repairs should be borne by the producer").

33. The parliamentary questions came from Members of the European Parliament with various national backgrounds. See, e.g., European Comm'n, Question for Written Answer to the Commission E-001284, EuropeAn PARLIAMENT (Feb. 14, 2011), www.europarl.europa.e $\mathrm{u} /$ sides/getDoc.do?pubRef=-//EP//TEXT+WQ+E-2011-001284+0+DOC+XML+V0//EN [ht tps://perma.cc/C5QT-GPL4] (posing a question on planned obsolescence from Spain); European Comm'n, Question for Written Answer to the Commission E-002875, EUROPEAN PARLIAMENT (Mar. 24, 2011), www.europarl.europa.eu/sides/getDoc.do?pubRef=-//EP//TE $\mathrm{XT}+\mathrm{WQ}+\mathrm{E}-2011-002875+0+\mathrm{DOC}+\mathrm{XML}+\mathrm{V} 0 / / \mathrm{EN}$ [https://perma.cc/4REA-YERC] (presenting a question on built-in obsolescence from Germany); European Comm'n, Question for Written Answer to the Commission E-004273, EuROPEAN PARLIAMENT (May 5, 2011), www.europarl.europa.eu/sides/getDoc.do?type=WQ\&reference=E-2011-004273\&la nguage $=\mathrm{EN}[\mathrm{https}: / /$ perma.cc/7MMV-GZ5X] (posing a question on planned obsolescence from Finland). 
guarantees [Consumer Sales Directives or CSD] offers to consumers minimum rights against sellers of faulty products, i.e. of products whose quality and performance are not normal in goods of the same type and cannot be reasonably expected by the consumers. These rights include the right to have a faulty product repaired or replaced free of charge or to obtain, under certain conditions, a refund or a price reduction within a period of two years from the delivery of the product. Member States may adopt more stringent provisions, i.e. longer guarantee periods, in their national legislations. ... Planned obsolescence clearly runs counter to the objectives set out by the Commission in its Europe 2020 strategy to achieve resource-efficient growth. An important element of resource efficiency is sustainable materials management. $^{34}$

In 2017, the European Parliament's Committee on Internal Market and Consumer Protection ("IMCO") joined the debate. Based on its 2017 report on "a longer lifetime for products: benefits for consumers and companies" (2017 IMCO Report), ${ }^{35}$ the IMCO suggested that warranty law could be considered as an ideal mechanism to answer the problem of planned obsolescence. IMCO argued that shortened periods of usability constitute defects relevant to warranty law if the reasonably expected lifetime is longer than the actual durability of the product. ${ }^{36}$

The claim that warranty law offers a solution to the planned obsolescence problem is worth further investigation. However, to assess its true potential, a more in-depth study of warranty law is required. Based on the assumption that regulatory differences exist, it is helpful to look at the possible impact and drawbacks in different jurisdictions of the use of warranty law in the area of planned obsolescence. Key questions to be addressed in Part III include: (1) Can planned obsolescence constitute a

34. European Comm'n, Joint Answer Given by Mr. Potočnik on Behalf of the Commission, Written Questions: E-001284/11, E-002875/11, E-004273/11, EUROPEAN PARLIAMENT (July 8, 2011), www.europarl.europa.eu/sides/getAllAnswers.do?reference=E2011-004273\&language=EN [https://perma.cc/G8S5-NFX6] (emphasis added).

35. IMCO, REPORT ON A LONGER LIFETIME FOR PRODUCTS: BENEFITS FOR CONSUMERS AND COMPANIES (2017), www.europarl.europa.eu/sides/getDoc.do?pubRef=-//EP//TEX T+REPORT+A8-2017-0214+0+DOC+XML+V0//EN [https://perma.cc/ZQ4H-7ZTL].

36. For further details, see IMCO, MOTION FOR A EUROPEAN PARLIAMENT RESOLUTION ON A Longer Lifetime for Products: Benefits for Consumers and Companies paras. 33-36 (2016), www.europarl.europa.eu/doceo/document/A-8-2017-0214EN.html\#title1 [htt ps://perma.cc/849Q-5GFD] (calling for the Commission to implement minimum requirements for product durability); see also id. at recital L (demonstrating that the IMCO explicitly refers to the framework created by the CSD). 
warranty relevant defect? (2) Against whom can such warranty claims be made? (3) What remedies should be provided for cases of planned obsolescence? (4) What adjustments to limitation periods will be needed to adequately protect purchasers of products against planned obsolescence?

\section{WARRANTY LAW AS A REGULATORY REGIME FOR PLANNED OBSOLESCENCE}

This Part provides a broad survey and examination of existing warranty law in the U.S., EU, the laws of individual European countries, and a representative sampling of the laws of other countries in the world. U.S. warranty law is found in a haphazard mix of federal and state laws ranging from the common law, federal regulatory law, state insurance law, and targeted state statutes, such as "lemon laws." The EU has a more advanced warranty law that is (partially) harmonized by a specific directive - the 1999 Consumer Sales Directive. ${ }^{37}$ Some EU Member States take a more active approach to product durability and planned obsolescence, which is discussed later in this Part.

\section{A. General Remarks and Findings}

With respect to the most fundamental question of whether cases of planned obsolescence, as understood in Vance Packard's notion of "obsolescence of quality," constitute defects relevant to warranty law, the working premise here is that in principle, regardless of the country or jurisdiction, this question can be widely answered in the affirmative. In a very simplified way, it can be generalized that the idea behind every warranty regime is to guarantee that purchasers receive products of a quality that they are reasonably entitled to receive. ${ }^{38}$ In cases of planned obsolescence, the purchaser of a good receives a product that is not of the quality owed under the contract (it fails to meet mutually agreed-upon quality standards) or fails to perform for a reasonably expected (implied) lifetime. The premature end of a product's lifetime, if regarded as substantial in nature, should be classified as a physical defect recognizable under warranty law.

As for the question of what purchasers may reasonably expect regarding the lifespan of a product, a two-step approach is warranted. First,

37. Council Directive 1999/44/EC, art. 2(2)(d), 1999 O.J. (L 171) 12.

38. This expectation may vary based upon the price charged, the state of the art in a given industry, and historical views of durability. 
one has to identify a group of comparable products and a margin of tolerance, or a product-group benchmark of durability, to measure acceptable durability deviations. Parameters such as the product price and product presentation and design influence whether a respective product reaches the threshold of the reasonable expectation of durability. Second, significant deviations from expected lifespans that go beyond an acceptable range of tolerance should result in planned obsolescence being recognized as a material defect under warranty law.

Supplementary evidence for cases of planned obsolescence is linked to technical advancement that renders earlier products obsolete in a functional way. Declining product lifetimes due to technical innovation should be recognized as cases of planned obsolescence and regulated accordingly. An example would be when an older generation of a smart phone or laptop computer is engineered to slow down to encourage the purchase of a newer generation of the product. Apple, for example, engineers computers to make it almost impossible or cost-prohibitive to replace the battery. Planned obsolescence of the computer is engineered by tying the usefulness of the computer to the lifespan of the battery. Allowing for the easy replacement of the battery would enhance the durability of the computer. Alternatively, failing to improve the lifespan of a product in new generations of a product, such as improving the battery life, is also evidence of planned obsolescence.

Appropriate remedies for the breach of an implied warranty of durability include repair and replacement of the defective product, price reduction or pro rata refunds, and the right of rescission. Some jurisdictions further allow for (more or less extensive) damages claims, sometimes adding to the list of non-fault remedies, and in other cases requiring fault on the side of the liable party. ${ }^{39}$ In most cases of warranty law, there is a combination of remedies offered to the purchaser of products, which is most commonly the seller's duty to repair or replace. In the U.S., warranty law generally can be read so that the manufacturer or seller has the right to select either repair or replacement of the product. The law should be reformed, for the purpose of fighting planned obsolescence, prevention of waste, and sustainability, by prioritizing repair as the preferred remedy over replacement. Repairing prolongs the lifespan

39. For the sake of focusing on the key topic of the underlying study, we will not comment on the fault/non-fault divide any further. It shall suffice to note that fault-based, damages-claim schemes are usually subject to longer prescription periods. The advantage of traditional warranty remedies, however, can be seen in the (principally) non-fault character of said tools. 
of the product; therefore, replacement should be viewed as the remedy of last resort.

Differences among jurisdictions include the parties recognized to bring warranty claims and the range that manufacturers are liable for in such claims. For example, can third parties harmed by the defect bring a claim? Another interesting example relates to the sale of Extended Warranties and Service Contracts ("EWSCs") involves numerous parties. In automobile sales, the retailer-seller of the automobile acts as the sales person. The EWSCs are, however, underwritten by the manufacturer or a third-party at the point of sale. Also, third-party companies through mail or telephone marketing sell EWSCs. Should the retailer be held partially liable for the selling of such extended warranties? How should the marketing of such warranty products be regulated? Generally speaking, one can distinguish between schemes under which only the contractual parties in a narrow sense (seller and the buyer of a defective product) would be involved (at least as a first step) and those solutions that would (additionally) apply direct producer liability.

Finally, the issue of limitation periods or statutes of limitation is of utmost relevance when it comes to claims for warranty remedies tied to planned obsolescence. Are limitations long enough to process claims of planned obsolescence or will most claims be barred by prescription time limits? Time is also of significance when it comes to the warranty period in a narrower sense. Does the warranty period provided by contract or law allow for sufficient time for planned obsolescence to become apparent?

\section{B. United States}

This section will examine American warranty law and introduce the independent warranty products known as EWSCs. Because the U.S. is a federation of states, most of contract law, as well as the associated area of warranty law, is found at the state level. The analogy to the EU is that member countries have the ability to provide greater restrictions or protections than are required under European Law, while in the case of the U.S., states have the ability to provide stricter protections than those found in federal law or other state laws. The benefit of states in the U.S. having their own common and statutory laws, as well as independent court systems, is that they provide the opportunity to experiment. Thus, law reform is enhanced as some states try different methods or laws to regulate abuse in the market place. Efficient and successful law reforms will often be replicated in other states. The drafting of model laws often assists the dissemination of law reform among American states. The most important 
drafts of model laws have come from collaborations between the American Law Institute ("ALI") and the National Association of State Commissioners on Uniform State Law ("NCCUSL"). ${ }^{40}$

Thus, warranty law in American law is found primarily at the state level, which may vary in content. However, numerous federal and state administrative agencies are delegated regulatory powers that have been used to police the marketplace. In the end, the American warranty system and approach is best described as a chaotic, piecemeal quilt of federal-state laws. In the area of planned obsolescence, American law is scarce as to the manufacturers' practice of producing goods that are meant to fail or have limited durability. The next few sections will analyze warranty law and its potential application to the problem of planned obsolescence.

\section{Federal Law}

Federal warranty law in the U.S. is found in the Magnuson-Moss Act ("MMA"). ${ }^{41}$ Unfortunately, the MMA's coverage of warranties is broad but short on specifics. The law is more about form than substance. It does not provide minimum standards for warranties; it mandates how warranty and warranty disclaimers are to be presented to the consumer (plain language and conspicuousness). Any consumer disclosure requirements only apply to the manufacturer and not to the retailer-seller.

It is important to note the differences between warranties that are attached to the contract of sale, usually the manufacturer's warranty, and warranty products separate from the sales contract that provide extended protections beyond the basic manufacturer-provided warranty. The product warranty comes within the scope of warranty law, while EWSCs ${ }^{42}$ are generally covered under state insurance law but are largely unregulated. At first glance, the idea of EWSCs seems to provide protection against planned obsolescence. In reality, the largest sellers of EWSCs are manufacturers that have inside knowledge of the durability of their products. There is a direct relationship between the sale of EWSCs, an

40. The creation of model state laws has a long tradition in the U.S. The ALI and the NCCUSL have worked together to draft numerous model laws that have been widely adopted by American states, such as the U.C.C.

41. Magnuson-Moss Warranty-Federal Trade Commission Improvement Act, Pub. L. No. 93-637, 88 Stat. 2183 (codified in scattered sections of 15 U.S.C.).

42. EWSCs are ubiquitous in the modern marketplace, offered at every automobile dealership and electronics and appliance store either by a salesperson or the cashier. Most sales of EWSCs result in price gouging due to informational asymmetry and behavioral manipulation. 
approximately $\$ 40$ to $\$ 50$ billion-dollar industry in the U.S. ${ }^{43}$ and planned obsolescence. $^{44}$ The EWSC market is characterized as unfair, nontransparent, and overreaching (price gouging). ${ }^{45}$

Regulation of EWSCs, much like general warranties, is a haphazard mix of federal and state regulations. Many of these regulations do not specifically target the EWSC but are extrapolated from long existing regulatory schemes, such as insurance and warranty law at the state level. There is no single regulatory authority at the federal or state levels whose scope extends to all legal issues relating to warranties or to the EWSC industry. Such a piecemeal approach leaves numerous gaps in the regulation of planned obsolescence, as well as incongruities in approach among the different U.S. states. The level of consumer protection in this area is lower than consumer protection laws tailored for specific industries and issues.

Since there is no independent consumer contract law or standard terms regulation in the U.S. as is found in Europe,${ }^{46}$ regulation of warranties and extended warranties, as previously stated, is relegated to a fragmented legal regime including common law, as well as state and federal regulatory law. The next sections review state law on warranties and extended warranties.

\section{State Law}

Given the federal government's failure to provide a comprehensive regulatory regime relating to warranties or the problem of obsolescence, most pertinent law is found at the state level. Again, no state provides targeted rules aimed at dealing with the issue of durability of products. Instead, regulation is found in a mix of different laws stemming from a

43. See Abhishek Yadav, Extended Warranty and Service Contract Industry USA (2015), https://www.slideshare.net/AbhishekYadav23/extended-warranty-industry-inus [https://perma.cc/5KWF-67NF] (detailing the scope of the EWSC industry based upon 2014 statistics).

44. Planned obsolescence has been defined as the use of "strategies and techniques of premature product aging applied by producers and sellers for the purpose of making end users replace old products with new ones faster than they ordinarily would by shortening the time of their use." Wrbka, Warranty Law in Cases of Planned Obsolescence - The Austrian Situation, supra note 12.

45. See Larry A. DiMatteo \& Stefan Wrbka, Planned Obsolescence and Consumer Protection: The Unregulated Extended Warranty and Service Contract Industry, 28 CoRnell J.L. \& PUB. POL'y 483 (2019) (explaining that ESWCs' premiums result in about an $80 \%$ profit margin and are sold through high pressure selling tactics).

46. See, e.g., Council Directive 93/13/EEC, 1993 O.J. (L 95) 29 (discussing unfair terms in consumer contracts). 
variety of sources. These sources include the U.C.C., state insurance law, and a handful of tailored laws, such as state "lemon" laws.

\section{a. Uniform Commercial Code}

In the U.S., the common law, found in individual state laws, fails to distinguish between commercial and consumer contracts, and except for a few exceptions in Article 2 of the U.C.C., does not distinguish between commercial and consumer sales of goods. ${ }^{47} \mathrm{Up}$ to the present, despite a host of consumer protection laws, American contract law remains generic in nature without any recognized body of consumer contract law. For example, fine print terms, often incorporated by reference, are enforceable whether they are found in consumer or commercial contracts. The exception is that the merchant-consumer distinction plays a role in the use of the doctrine of unconscionability found in the U.C.C., and, as applied by analogy to other types of contracts, is in practice used exclusively to void terms in consumer contracts. This is despite the fact that as written, U.C.C. section 2-302 equally applies to commercial contracts. The bargaining power and informational imbalances found in consumer contracts has been the linchpin for the application of the doctrine of unconscionability. ${ }^{48}$ However, it is important to note that the general rule is that one-sided (promerchant) terms in a consumer contract are enforced, and that the unconscionability doctrine is only applied in ad hoc cases and cannot itself

47. The handful of provisions in the U.C.C. that provides additional protections is collectively noted as the merchant-consumer distinction. Except for these few provisions, the U.C.C. applies equally to commercial and consumer transactions. See generally Ingrid M. Hillinger, The Article 2 Merchant Rules: Karl Llewellyn's Attempt to Achieve the Good, the True, the Beautiful in Commercial Law, 73 Geo. L.J. 1141, 1184 (1985) ("Other scholars as well have noted the doctrinal confusion and poor results that flow from a unitary approach to situations involving different issues and policy concerns."); Zipporah B. Wiseman, The Limits of Vision: Karl Llewellyn and the Merchant Rules, 100 HARV. L. REV. 465, 494 (1987) (explaining that merchant associations wielded too much power in the unregulated marketplace). The term consumer is not defined in the U.C.C., but merchant is defined: “MERCHANT' means a person who deals in goods of the kind or otherwise by his occupation holds himself out as having knowledge or skill peculiar to the practices or goods involved in the transaction or to whom such knowledge or skill may be attributed by his employment of an agent or broker or other intermediary who by his occupation holds himself out as having such knowledge or skill." U.C.C. § 2-104 (AM. LAW INST. \& UNIF. LAW COMM'N 2012).

48. Charles L. Knapp, Unconscionability in American Contract Law: A Twenty-First Century Survey, in Commercial Contract Law: A Transatlantic Perspective 309 (Larry A. DiMatteo et al. eds., 2013) (noting that the U.S. Supreme Court has narrowed the use of unconscionability to void arbitration clauses in consumer contracts). 
be considered a form of standard terms regulation. There is no "fairness concept" as found in the EU Unfair Terms in Consumer Contracts, ${ }^{49}$ or "surprising terms" principle found in German law, ${ }^{50}$ in American contract law.

A seller of goods is not obligated to provide a warranty. However, if given, any contract language that attempts to limit the scope of an express warranty is unenforceable. ${ }^{51}$ The U.C.C. implies certain warranties, whether or not an express warranty is provided. The implied warranty of merchantability ${ }^{52}$ and implied warranty for a particular purpose $\mathrm{e}^{53}$ are attached to sale of goods contracts unless expressly disclaimed. However, section 2-316(2) limits the effectiveness of a disclaimer. First, to exclude the implied warranty of merchantability the disclaimer must explicitly use the word "merchantability." Second, the disclaimer language must be presented in a conspicuous manner. But these requirements are simply formalities, easily surmounted by boilerplate disclaimer clauses. However, violations of the warranty provisions of the U.C.C. make manufacturers susceptible to claims under the Federal Trade Commission Act. ${ }^{54}$ Section 5(a) of the FTC Act simply states in broad terms that any "[u]nfair methods of competition in or affecting commerce, and unfair or deceptive acts or practices in or affecting commerce, are hereby declared unlawful. ${ }^{55}$ The Act assigns regulatory authority to the Federal Trade Commission. Violations can be punished by civil penalties of $\$ 10,000$ per unfair act. ${ }^{56}$

49. See also Council Directive 93/13/EEC, supra note 46 (applying fairness assessments to consumer contract terms); see also Council Directive 2011/83/EU, 2011 O.J. (L 304) 64 (applying fairness assessments to unfair terms in consumer contracts).

50. Bürgerliches Gesetzbuch [BGB] [Civil Code], $\S 305 \mathrm{c}$, para. 1, sentence 1, https://www.gesetze-im-internet.de/englisch_bgb/englisch_bgb.html\#p0930

[https://perma.cc/37KW-XPHR] (Ger.) (stating under the "Surprising and ambiguous clauses" heading that "[p]rovisions in standard business terms which . . . are so unusual that the other party to the contract with the user need not expect to encounter them, do not from part of the contract").

51. U.C.C. § 2-316(1) (AM. LAW Inst. \& UnIF. LAW Comm'N 2012) ("Words or conduct relevant to the creation of an express warranty and words or conduct tending to negate or limit warranty shall be construed wherever reasonable as consistent with each other; but... negation or limitation is inoperative to the extent that such construction is unreasonable.").

52. U.C.C. § 2-314 (Am. LAw InSt. \& UNIF. LAw COMM’N 2012).

53. $I d . \S 2-315$.

54. Federal Trade Commission Act, 15 U.S.C. $\S \S 41-58$ (2018).

55. 15 U.S.C. $\S 45(\mathrm{a})(1)(2018)$.

56. Id. $\S 45(\mathrm{~m})$. See also Bureau of Consumer Protection: File a Complaint, FED. TRADE COMMISSION, https://www.ftc.gov/about-ftc/bureaus-offices/bureau-consumer-prote ction [https://perma.cc/BGN4-CFQV] (last visited Aug. 12, 2019) (allowing consumers to 
Again, unfortunately warranty law does not currently regulate EWSCs since it focuses on product warranties, which are part and parcel to the product being sold, normally given by the manufacturer of the products. EWSCs are considered a separate product from the standard warranty provided in the sale. The EWSC is independent of the sale of the good, for which the consumer pays an additional price. However, there is little reason that the conspicuousness and plain language requirements should not be extended to EWSCs. The lack of federal regulation leaves it to state law to provide governance. Unfortunately, such state regulation is also lacking or sporadic, especially given that there is no existing model law on the subject. The state regulatory law closest to EWSCs is found in insurance law. For example, New York Insurance Law applies to certain service contracts and commercial guarantees, which is discussed in the next section.

In section 2-316(2), to exclude or modify any implied warranty of fitness, the exclusion must be in writing and conspicuous. Language to exclude all implied warranties of fitness is sufficient if it states, for example, that "[t]here are no warranties which extend beyond the description on the face hereof.",57

The implied warranties, provided in subsections 2-314 and 2-315, are narrowed subsequently in subsection 2-316(3). It provides that certain phrases such as sold "as is," "with all faults," or "other language which in common understanding," exclude all implied warranties. ${ }^{58}$ A buyer's inspection of goods or refusal to examine the goods may also serve to exclude the implied warranties in cases where such an examination would have revealed the pertinent defects. ${ }^{59}$ Finally, section 2-316(3) provides that: "An implied warranty can also be excluded or modified by course of dealing or course of performance or usage of trade." ${ }^{, 60}$ More importantly, section 2-316(2) allows sellers and manufacturers to disclaim the implied warranties as long as the disclaimers conform to the above-mentioned formulaic requirements. ${ }^{61}$

file complaints through the Federal Trade Commission's Bureau of Consumer Protection).

57. U.C.C. § 2-316(2) (AM. LAW INST. \& UNIF. LAW COMM’N 2012).

58. Id. $\S 2-316(3)(\mathrm{a})$.

59. Id. $\S 2-316(3)(\mathrm{b})$.

60. Id. $\S 2-316(3)(\mathrm{c})$.

61. "[T]o exclude or modify the implied warranty of merchantability or any part of it the language must mention merchantability and in case of a writing must be conspicuous, and to exclude or modify any implied warranty of fitness the exclusion must be by a writing and conspicuous. Language to exclude all implied warranties of fitness is sufficient if it states, for example that 'There are no warranties which extend beyond the description on the 
Section 2-317 provides that in determining the contracting parties' intent, courts should weigh the following factors:

(a) Exact or technical specifications displace an inconsistent sample or model or general language of description.

(b) A sample from an existing bulk displaces inconsistent general language of description.

(c) Express warranties displace inconsistent implied warranties other than an implied warranty of fitness for a particular purpose. $^{62}$

In cases of personal injury caused by defective products, section 2-318 of the U.C.C. says that injured third parties are given a direct cause of action against the manufacturer. ${ }^{63}$ This non-claimable warranty extends express and implied warranties to specific third parties. ${ }^{64}$ It states that the warranty "extends to any natural person who may reasonably be expected to use, consume or be affected by the goods and who is injured in person by breach of the warranty." 65

The U.C.C. provides a limitation period for claims to be brought within a period of four years. ${ }^{66}$ However, it also provides that the contracting parties may agree to reduce it to one year, and that they "may not extend it." ${ }^{, 67}$ Regarding latent defects, it provides that:

[a] breach of warranty occurs when tender of delivery is made, except that where a warranty explicitly extends to future

face hereof." "U.C.C. § 2-318(2) (AM. LAW InST. \& UNIF. LAW COMM'N 2012).

62. U.C.C. § 2-317(3)(c) (AM. LAW InST. \& UNIF. LAW COMM’N 2012).

63. U.C.C. $§ 2-318$ is titled "Third Party Beneficiaries of Warranties Express or Implied.” U.C.C. § 2-318 (AM. LAW INST. \& UNIF. LAW COMM’N 2012).

64. Section 2-318 of the U.C.C. model law provides states with a choice of three alternatives: "Alternative A: A seller's warranty whether express or implied extends to any natural person who is in the family or household of his buyer or who is a guest in his home if it is reasonable to expect that such person may use, consume or be affected by the goods and who is injured in person by breach of the warranty. A seller may not exclude or limit the operation of this section. Alternative B: A seller's warranty whether express or implied extends to any natural person who may reasonably be expected to use, consume or be affected by the goods and who is injured in person by breach of the warranty. A seller may not exclude or limit the operation of this section. Alternative C: A seller's warranty whether express or implied extends to any person who may reasonably be expected to use, consume or be affected by the goods and who is injured by breach of the warranty. A seller may not exclude or limit the operation of this section with respect to injury to the person of an individual to whom the warranty extends."

U.C.C. § 2-318 (AM. LAW InST. \& UNIF. LAW COMM’N 2012).

65. U.C.C. \$2-318 (AM. LAW InST. \& UNIF. LAW COMM’N 2012).

66. Id. $\S 2-725$.

67. Id. $\S 2-725(1)$. 
performance of the goods and discovery of the breach must await the time of such performance the cause of action accrues when the breach is or should have been discovered. ${ }^{68}$

\section{b. Extended Warranties and State Insurance Law}

Technically, EWSCs are regulated under state insurance laws. Given its prominence in the area of commercial law, New York State ("NYS") Insurance Law will be reviewed here. NYS Insurance Law makes a distinction between warranty and service contracts. Generally, warranties are not within the scope of insurance law, while service contracts are regulated by the NYS Department of Insurance. The law defines a service contract as an "agreement, for a separate or additional consideration, for a specific duration to perform the repair, replacement or maintenance of property, or indemnification for repair, replacement or maintenance, due to a defect in materials or workmanship or wear and tear." ${ }^{, 69}$

However, that regulation simply requires registration, certification, licensing, and conforming to solvency regulations. ${ }^{70}$ The third-party insurer-provider of the service contract is required to meet these requirements, but neither the retailer nor the seller nor the contractor providing the services or doing the repairs must meet these requirements. However, a company independent of the third-party insurer must meet these requirements if "it actually obligates itself to make repairs and maintenance under a service contract, in which case it would have to register as a service contract provider." ${ }^{71}$

The Insurance Law does not require a service contract provider to file their rates and contract forms for review by the Department. Article 79, entitled "Service Contracts," states that its purposes are to "create a legal framework within which service contracts may be sold in this state; encourage the marketing and developing of more economical and effective means of providing services under service contracts; and permit and encourage fair and effective competition among different systems of providing and paying for these services." ${ }^{72}$ The Article authorizes the

68. Id. $\S 2-725(2)$.

69. N.Y. INS. LAW § 7902(k) (Consol. 2019).

70. It also requires the insurer to maintain reserve funds in the amount of not less than $5 \%$ of the price of the contracts sold. N.Y. INS. LAW $\S 7903$ (c) (Consol. 2019).

71. Dep't of Fin. Servs., Re: Licensing/Registration Requirements for Service Contract Providers, N.Y. ST. (June 3, 2002), https://www.dfs.ny.gov/insurance/ogco2002/rg206033.ht m [https://perma.cc/GB9D-QH3K].

72. N.Y. INS. Law $\S 7901$ (Consol. 2019). 
Superintendent of Insurance to enforce the law, conduct investigations, issue cease and desist orders, and collect a statutory penalty in the amount of $\$ 500$ per violation. ${ }^{73}$

The key is what distinguishes extended warranties from a service contract under NYS Insurance Law. First, the service contract is independent of the product itself. However, if the manufacturer is the underwriter or provider of the service contract, then it is not covered under insurance law. Second, if the EWSC coverage insures against a risk external ("fortuitous risk") to the product, then it is deemed to be a service contract. In one case, a third-party insurer provided protection for restaurant equipment against damage due to a fire. The Office of General Counsel held that the product was a service contract since the third-party was undertaking an obligation that involved a fortuitous risk, thereby making it a type of insurance. ${ }^{74}$

Another New York case involved the sale of a new tire with a "road hazard warranty program.." ${ }^{, 5}$ The product included placing a sealant on the tire to provide added protection. But it is not the product that is being warranted; it is insuring the tire from harm external to the product. The Product Warranty is not related to any defect in materials or workmanship in the tires, but rather is based upon the failure of the product to prevent damage to the tires from road hazards. The Office of General Counsel reasoned that if "the tire [is] damaged due to a road hazard, it is not because the product did not work as intended to prevent drying out or rotting of the tire, but rather it is because there was something in the roadway, an intervening 'fortuitous event," within the meaning of the Insurance Law. ${ }^{76}$ Road hazards (such as a nail on the road) are outside the control of either the provider of the warranty or the car dealer who sells the warranty. Since the warranty was independent of the product and insured against a fortuitous event, it was held that the warranty was a service contract. In either situation, the service contract provider and any administrator liability are subject to NYS Insurance Law, and thereby liable for the damage to the tire since it was due to a protected occurrence. ${ }^{77}$

73. Id.

74. Dep't of Fin. Servs., Re: Marketing an Extended Warranty Program, N.Y. ST. (Sept. 17, 2007), http://www.dfs.ny.gov/insurance/ogco2007/rg070915.htm [https://perma.c c/X7FY-GDJQ].

75. Dep't of Fin. Servs., Re: The Product Warranty of a Tire Product, N.Y. ST. (May 11, 2004), http://www.dfs.ny.gov/insurance/ogco2004/rg040512.htm [https://perma.cc/6DE M-AN7Z].

76. Id.

77. Administrator is defined as a "person designated by a service contract provider who 
Some ESWCs may restrict transfers of the contract to future owners. For example, a home purchaser or owner buys an EWSC. Does the purchaser-owner have the right to transfer the contract when she resells the home with time remaining on the EWSC? If not, should the third-party insurer be required to refund a pro rata amount of the contract price? NYS Insurance Law simply requires that service contracts "state any terms, restrictions or conditions governing the transferability of such service contracts." $^{\text {"78 }}$ But, other than this disclosure requirement, as a general matter, the transferability of a service contract depends upon the provisions in the specific contract in question including a non-transferability provision. The law also requires the service contract to "specify any limitations on the right to terminate the service contract by the provider or contract holder" and the right, if any, to receive a refund. ${ }^{79}$ The law does not deal with the issue of whether the seller or provider of the EWSC should be able to assign the contract to another party, which may provide lower cost and lower quality services.

A more proactive provision of NYS Insurance Law provides a right of rescission in which a purchaser of a service contract has ten days, and sometimes twenty days, to rescind the contract unless the purchaser had already filed a claim. ${ }^{80}$ The third-party insurer must give a refund in full within thirty days of receiving the notice of rescission. If the third-party insurer-provider fails to make a timely refund, then it must pay the holder an additional ten percent, as well as an additional ten percent penalty for each subsequent month until the refund is paid. ${ }^{81}$

In sum, service contracts and extended warranties for which a separate, identifiable price is charged are subject to state regulation. Specifically, state insurance regulators in approximately thirty states have some oversight over providers of service contracts and extended warranties. These regulations vary widely, from state requirements that service contract and extended warranty providers be licensed as insurance companies (Georgia Code $\S 33-7-6(3),{ }^{82}$ which treat service warranties as a form of property insurance) to requirements that providers register as "service contract providers" (Minnesota Statute $\S 59 \mathrm{~B} .03$ requires all

in this state markets, sells, offers for sale, issues, makes, proposes to make or administer service contracts." N.Y. INS. LAW § 2101(a)(5) (Consol. 2019).

78. N.Y. INS. LAW $\S 7905(j)$ (Consol. 2019).

79. N.Y. Comp. Codes R. \& Regs. tit. 11, § 390.5(a) (1999).

80. N.Y. INS. LAW $\S 7903($ e) (McKinney 2000).

81. Id.

82. GA. CODE $§ 33-7-6(3)$ (2010). 
providers of service warranties to register with the Minnesota Division of Insurance and pay a $\$ 750$ annual registration fee). ${ }^{83}$ While many of the states that regulate service contract and extended warranty providers do not follow it precisely, the National Association of Insurance Commissioners' Service Contracts Model Act (Model Act) is one frequent source for state legislation on this issue and numerous states have adopted a form of the Model Act. Any manufacturer contemplating its own service contract or extended warranty program should review this Model Act. ${ }^{84}$

Section 3905.42 of the Ohio Revised Code requires sellers of insurance to be licensed under the state's insurance law. ${ }^{85}$ An insurance provider is anyone who "enter[s] into any contracts substantially amounting to insurance." 86 Service contracts are generally considered as a form of insurance. $^{87}$ However, extended warranties or service contracts relating to the sale of automobiles are not considered an insurance product under Ohio law, ${ }^{88}$ except for specific types of hazards, such as vehicle protection systems (risk of theft), ${ }^{89}$ glass protection, and protection against minor dents to the exterior. ${ }^{90}$

New Jersey law broadly defines a service contract as:

'Service contract' means a contract or agreement between a provider and a consumer for any duration, for a provider fee or other separately stated consideration, to perform, or to provide indemnification for the performance of, the maintenance, repair, replacement, or service of property for the operational or

83. Minn. STAT. § 59B.03 (2018).

84. Nat'l Ass'n of Ins. Comm'rs, Service Contracts Model Act (1997), https://www.naic.org/store/free/MDL-685.pdf [https://perma.cc/JE39-4ECK].

85. Ohio Rev. Code ANN. § 3905.42 (LexisNexis 2019).

86. Id.

87. For example, home service contracts are expressly considered a type of insurance. “"Home service contract' means a contract, however described or denominated by the issuer of the contract, whereby, for a predetermined fee, a person undertakes to repair or replace all or any part of any structural component, appliance, or system of a home necessitated by wear and tear, deterioration, or inherent defect that occurs on or after the effective date of the home service contract." OHIO REv. CoDE ANN. § 3905.422(A)(1) (LexisNexis 2019).

88. "[A] contract or agreement to perform or pay for the repair, replacement, or maintenance of a motor vehicle due to defect in materials or workmanship, normal wear and tear, mechanical or electrical breakdown, or failure of parts or equipment of a motor vehicle ... that is effective for a specified duration and paid for by means other than the purchase of a motor vehicle." OHIo REv. CODE ANN. § 3905.426(A)(4) (LexisNexis 2019).

89. Ohio Rev. Code AnN. § 3905.421 (LexisNexis 2006) (stating, however, that a supplier may exclude any such warranty as an insurance product).

90. Id. $\S 3905.426(\mathrm{~A})(3)(\mathrm{i}-\mathrm{ii})$ (discussing the types of glass replacement and dent removal that are permitted). 
structural failure of the property due to a defect in materials or workmanship or due to normal wear and tear, and which may include additional provisions for incidental payment of indemnity under limited circumstances. $^{91}$

The statute goes on to distinguish between service contracts and warranties, noting that the law does not cover warranties and maintenance agreements. ${ }^{92}$ A warranty is defined as something "made solely by the manufacturer, importer, or seller of property or services without additional consideration, that is incidental to, and not negotiated or separated from, the sale of the property or services." 93 Thus, it can be inferred that EWSCs, which are a separate warranty from the standard manufacturer's warranty, are separate from the sales contract, and for which the buyer pays an additional price, are covered by the statute. Importantly, the statute provides that the EWSC must provide for a ten to twenty-day right of rescission or termination, which requires a full refund within forty-five days of the notice of cancellation. ${ }^{94}$

The Illinois "Service Contract Act" more clearly states that a service contract:

means a contract or agreement whereby a service contract provider undertakes for a specified period of time, for separate and identifiable consideration, to perform the repair, replacement, or maintenance, or indemnification for such services, of any automobile, system, or consumer product in connection with the operational or structural failure due to a defect in materials or workmanship, or normal wear and tear. ${ }^{95}$

The Illinois law provides a more robust right of rescission, allowing the purchaser to cancel within thirty days of purchase. Furthermore, the purchaser may cancel anytime thereafter and receive a pro rata refund for the unexpired term of the service contract. ${ }^{96}$

When offering service contracts or extended warranties on their own products, manufacturers are often exempt from licensing and registration requirements to which other non-manufacturer service contract or extended

91. N.J. STAT. § 56:12-87 (2014).

92. Id. $\S 56: 12-88(\mathrm{~b})(1)-(2)(2014)$.

93. Id. § 56:12-87 (2014).

94. Id. $\S 56: 12-93(\mathrm{k})(2014)$ (limiting the cancellation period to ten days from receipt of the EWSC or twenty days from which the EWSC was sent to the purchaser).

95. 215 Ill. COMP. Stat. 152/5 (1998) (excluding manufacturers' warranties in the same manner as the New Jersey statute: "vehicle product protection warranty included, for no separate consideration").

96. Id. 52/35(a) (1998). 
warranty companies would be subject. For example, in Utah, which requires service contract and extended warranty companies to register with the state insurance regulator, ${ }^{97}$ a manufacturer offering service contracts for its own products is exempt from the registration requirements and from oversight and regulation by the state insurance regulator. ${ }^{98}$ In Utah, this exemption extends beyond the manufacturer to its affiliates and subsidiaries as well. Other states, like Kansas, exempt only the manufacturer and not its affiliates and subsidiaries. ${ }^{99}$ Yet other states, like North Carolina, provide an exemption for manufacturers and distributors, but not other affiliates and subsidiaries of a manufacturer..$^{100}$

Not all states provide manufacturer exemptions from licensure or registration as a service contract or extended warranty provider. Even in states where there is a manufacturer exemption from licensure or registration, manufacturers often must comply with state laws and regulations governing the form and contents of service contracts and extended warranties. Accordingly, a manufacturer that seeks to offer its own extended warranty or service contract alongside its products (rather than allowing the profits to go to third-party providers) must plan on complying with varying state laws requiring registration or limited licensure with state insurance regulators. Despite these requirements, manufacturers face a lower overall regulatory burden in offering service contracts or extended warranties as compared to third-party providers.

\section{c. Lemon Laws}

Most American states have enacted some form of lemon law; however, the content of those laws vary. They are most commonly associated with the sale of motor vehicles but can also extend to the sales of heavy equipment and electrical appliances. The standard warranty law in the US only requires the seller to repair or replace defective products. In the area of "big ticket" items, such as automobiles, the manufacturer-seller will almost always choose the repair remedy in order to avoid the more costly remedy of replacement. This causes hardship on the purchaser and an avenue of abuse for the seller. If a defect proves difficult to rectify, requiring numerous trips for repair, or new types of defects continue to

97. Utah Code AnN. § 31A-6a-103 (LexisNexis 2015).

98. Utah Code AnN. § 31A-6a-102(3) (LexisNexis 2001); Utah Code AnN. § 31A-1103(3)(i) (LexisNexis 2017); UTAH CODE ANN. § 31A-1-103(6)(a) (2017).

99. KAN. STAT. ANN. § 40-201a (2017).

100. N.C. Gen. Stat. § 58-1-15(2)(b) (1985). 
appear over time, then the purchaser suffers a great deal of inconvenience and loses trust in the durability of the product. A seller may use the repair remedy in bad faith until the warranty period expires, leaving the purchaser without further recourse for subsequent defects. Of course, this is a scenario where an EWSC would prove desirable. However, if lacking a right to replacement, the same type of inconvenience and harm would occur, which lemon laws attempt to prevent.

But as noted earlier, most products are manufactured to last for the duration of the express warranty under the sales contract and the period of coverage of an EWSC. Otherwise, the ability to generate large revenue streams through the sale of EWSCs would not be possible. Nonetheless, there are at least some products that are shoddy, due to faulty assembly or the use of lower quality materials and component parts, which make them "lemons." The lemon laws preempt the remedial structure of warranty law by converting the seller's option of making continuous repairs to a buyer's right to a replacement or refund. ${ }^{101}$ This type of right should be included in EWSCs when a product is in constant need of repair during the period of coverage.

\section{d. Restatement of Consumer Contract Law}

The EWSC is essentially a consumer standard form contract. As previously stated, there are no general standard term regulations and separate consumer contract law in the U.S. as is found in Europe. However, the ALI recently sponsored the drafting of a Restatement of Consumer Contract Law. ${ }^{102}$ The new Restatement project can be seen as a supplement to the Restatement Second of Contracts and U.C.C. but that is dedicated to transactions made solely by consumers. ${ }^{103}$ The reporters of the Restatement recognize that "[c]onsumer contracts present a fundamental challenge to the law of contracts, arising from the asymmetry in information, sophistication, and stakes between the parties to these

101. It should be noted that most state lemon laws, as well as the Federal MagnusonMoss Act, allow the purchaser to claim the costs of legal fees as damages, which is a rarity in the American legal fee system.

102. Restatement of the Law, Consumer Contracts, A.L.I., https://www.ali.org/projects/s how/consumer-contracts [https://perma.cc/YC38-FPJA] (last viewed July 18, 2018). All nine sections of the Restatement have been drafted, and the initial draft was presented for discussion at the 2017 ALI Annual Meeting. It is expected to be re-presented at the 2019 Meeting.

103. Restatement (SECOND) OF Contracts (AM. LAw Inst. 1981). 
contracts - the business and the consumers." ${ }^{104}$ They list two techniques for preventing consumer abuse in contracts: (1) assuring mutual assent by focusing on the rules that determine how terms are adopted and which processes a business can use to introduce and modify terms in the agreement; and (2) the use of mandatory restrictions over the substance of the deal - rules that limit the discretion of the business in drafting contract terms, and the setting of boundaries on permissible contracting. ${ }^{105}$ In essence, the Restatement project is a soft-law form of European standard terms regulation. ${ }^{106}$

Its goal is to take the first step in creating a separate body of consumer contract law by first, recognizing specific contract law rules that only apply to consumer transactions, and second, incorporating existing government regulations of the consumer marketplace into a standalone consumer contract law. This would include: (1) formulating "principles for punitive treatment of some types of willful breaches of consumer contracts"; ${ }^{107}$ (2) "[u]nifying the framework" for developing rules mandating pro-consumer terms and banning terms that are deemed to be abusive"; ${ }^{108}$ (3) clarifying the contours of the unconscionability doctrine, including how it applies in the area of arbitration ("one goal will be to translate research on consumer decision-making, and on the limits of consumer understanding, into specific guidelines for the courts"); ${ }^{109}$ and (4) distilling "the common principles that ought to guide" courts in applying the FTC Act and state laws prohibiting "unfair or deceptive" acts or practices and the DoddFrank ${ }^{110}$ prohibition on "unfair, deceptive or abusive" acts or practices. ${ }^{111}$

Unfortunately, the proposed Restatement places emphasis on the first

104. Am. Law Inst., Restatement of the Law: Consumer Contracts 1 (2019), htt ps://www.ali.org/media/filer_public/05/30/053007a1-2b37-4142-b9c3-

7a881e847d50/consumer_contracts_-_td_-_online.pdf [https://perma.cc/8NCT-EPX5].

105. Id.

106. For example, the Restatement Draft has sections titled "Adoption of Standard Contract Terms" (\$2) and "Modification of Standard Contract terms" (\$3).

107. ALI Launches Restatement Project for Consumer Contracts, BALLARD SPAHR (Dec. 6, 2012), https://www.ballardspahr.com/alertspublications/legalalerts/2012-12-06-ali-launch es-restatement-project-for-consumer-contracts [https://perma.cc/ANW5-WBE4].

108. Id.

109. Id.

110. Dodd-Frank Wall Street Reform and Consumer Protection Act, Pub. L. No. 111203, 124 Stat. 1376 (codified in various titles of the U.S. Code) (establishing the Consumer Financial Protection Bureau as an agency responsible for consumer protection in the financial sector, and showing one of the Act's purposes through its own title: "to protect consumers from abusive financial services practices").

111. Id. 
of the aforementioned two techniques by re-emphasizing the importance of consent and de-emphasizing the importance of mandatory regulations aimed at setting boundaries of impressible consumer contracting (restrictive consumer-specific rules). For example, Section 2 provides rules on the adoption of standard contract terms. ${ }^{112}$ It provides that a consumer manifests assent to the transaction as long as she is given reasonable notice of the standard terms and a reasonable opportunity to review them. This does little to ensure the quality of the consent under the reality that most consumers do not read or understand such terms; this is especially common where the standard contract is long and detailed.

The unitary concept of consent, generally resting on a person's agreement or signing of a contract, fails to recognize the absence of true consent (understanding of agreement) found in many consumer contracts. The Restatement does provide for the buttressing of consent through precontract disclosures. Thus, the unitary construct of consent is modified in consumer contracts to mean only consent that is adequately informed. ${ }^{113}$ In the case of EWSCs, disclosures on the risk of needing repairs, costs, and rights would be helpful, but only if the disclosures are meaningful. For example, the disclosure should state whether the purchaser has a right of rescission and whether the contract is transferable. Also, disclosure is not meaningful if it is buried in lengthy, fine-print contracts. The seller should be required to ensure that the purchaser is aware of key options, restrictions, and rights.

Instead of standard terms regulations, the Restatement advocates for expanded judicial review of consumer contract terms to ensure a fair bargain. In order to insure such an outcome, Section 5 "encourages" the courts to more aggressively use the doctrine of unconscionability. ${ }^{114}$ This fails to recognize that more and more businesses are inserting arbitration clauses into their contracts. Although the doctrine of unconscionability has been used to void unfair arbitration clauses that leave a consumer without adequate recourse to seek a remedy, recent trends in this area do not bode well for consumers. The U.S. Supreme Court has re-emphasized that arbitration is the preferred means of dispute resolution under the Federal Arbitration Act, while at the same time limiting consumers' ability to

112. Florence Marotta-Wurgler, Omri Ben-Sharar \& Oren Bar-Gill, Adoption of Standard Contract Terms, ALI ADVISER (Apr. 27, 2017), http://www.thealiadviser.org/cons umer-contracts/adoption-standard-contract-terms [https://perma.cc/H2RP-LDDR].

113. AM. LAW INST., supra note 104, at 5-6.

114. Id. at 90. 
obtain arbitration. ${ }^{115}$ It has held that contract clauses waiving the consumer's right to join class action arbitration are enforceable. ${ }^{116}$ In the end, it is likely to be a very long time, if and when the Restatement of Consumer Contract Law is adopted, before courts recognize and use its provisions, and there is greater uncertainty if and how it is likely to impact consumer abuse in the sales of EWSCs. The Restatement project, however, does provide options and concepts that could be incorporated into future regulatory initiatives relating to EWSCs. The relationship between EWSCs, warranty law, and planned obsolescence will be revisited in Part IV.

\section{European Union}

This section reviews European warranty law and its intersection with the problem of planned obsolescence. It first highlights pertinent legal norms issued by the EU and then examples of the law in a variety of countries.

\section{Situation at the Pan-EU Level}

With the 1999 Consumer Sales Directive (CSD), the EU set binding minimum warranty standards with respect to consumer and $\mathrm{B} 2 \mathrm{C}$ sales. ${ }^{117}$ These common minimum standards include the following key points:

- Warranty law constitutes a non-fault element of contract law. In $\mathrm{B} 2 \mathrm{C}$ contracts the protection offered under the CSD is mandatory and hence cannot be excluded or lowered.

- Pursuant to Article 2(1) of the CSD delivered goods have to be "in conformity with the contract." 118 This includes "the quality and performance which are normal in goods of the same type and which the consumer can reasonably expect." 119 The durability of products arguably falls under the "quality" pillar. $^{120}$

115. Federal Arbitration Act, 9 U.S.C. $\$ \S 1-15$ (1925).

116. DIRECTV, Inc. v. Imburgia, 136 S. Ct. 463 (2015) (finding that class action waivers contained in arbitration agreements are enforceable under the Federal Arbitration Act and cannot be invalidated on state law grounds).

117. Council Directive 1999/44/EC, 1999 O.J. (L 171) 12.

118. Id. art. 2(1).

119. Id. art. $2(2)(\mathrm{d})$

120. In a similar vein, for example, the European Commission argues that planned obsolescence contradicts the "quality to be reasonably expected" rule. European Comm'n, 
- The liable party under the CSD is the seller of the defective product (and not the producer). This basic rule can be found in all Member States. Some Member States apply systems that allow for an additional non-fault direct producers' liability. ${ }^{12}$

- Article 3 of the CSD introduces a two-tiered remedial scheme. Repair and replacement enjoy priority over price reduction and rescission. Purchasers can, in principle, freely choose between repair and replacement.

- The relevant point for assessing contractual conformity is the point of delivery of the product. Latent defects are relevant insofar as they (or their origins) can be traced back to the point of delivery. Article 5(3) of the CSD stipulates that "[u]nless proved otherwise, any lack of conformity which becomes apparent within six months of delivery of the goods shall be presumed to have existed at the time of delivery unless this presumption is incompatible with the nature of the goods or the nature of the lack of conformity.,"122

All Member States have implemented the CSD. As we will see later in this section, some Member States went further by either maintaining an already purchaser-friendly standard or establishing higher protections than those provided in the CSD. ${ }^{123}$ This is permitted by the CSD, as the Directive aimed to introduce a common, minimum level of protection (minimum harmonization approach enshrined in Article 8(2) of the CSD). ${ }^{124}$

Taking a closer look at the situation in the Member States, despite the existence of minimum levels of protection, warranty periods and limitation or prescription periods pose challenges for some of the jurisdictions in

supra note 34.

121. For details, see ECC-Net, Commercial Warranties: Are They Worth the Money? 102-03 (2014), https://www.ecc.fi/globalassets/ecc/ajankohtaista/julkaisut/garantie sfinal-optimized.pdf [https://perma.cc/5LP5-V8VM] (comparing guarantee and warranty laws in EU member states, Iceland, and Norway).

122. Council Directive 1999/44/EC, art. 5(3), 1999 O.J. (L 171) 12.

123. For a detailed, early overview of the situation in the Member States, see Universität Bielefeld, EC CONSUMER LAw COMPENDIUM: COMPARATIVE ANAlysis 646 (Hans SchulteNölke et al. eds., 2008) (noting that all member states have taken steps to amend their domestic law to give effect to legislation which provides a higher level of protection for consumers).

124. Article 8(2) of the CSD reads as follows: "Member States may adopt or maintain in force more stringent provisions, compatible with the Treaty in the field covered by this Directive, to ensure a higher level of consumer protection." Council Directive 1999/44/EC, art. 2(2)(d), art. 8(2), 1999 O.J. (L 171) 12. 
applying warranty law to planned obsolescence. Warranty-relevant time concepts differ widely between the Member States. This is mainly due to the fact that the CSD itself differentiates between two timeframes and allows Member States to apply stricter, purchaser-friendly approaches. The issue of time is particularly crucial in the context of planned obsolescence because relevant defects are inherently latent and often become apparent only after the passage of a considerable amount of time.

Article 5(1) of the CSD establishes two periods and by doing this applies a two-tiered model. Article 5(1) Sentence 1 of the CSD introduces - as a minimum level-liability for defects that become "apparent within two years from delivery of the goods." 125 Pursuant to Article 5(1) Sentence 2 of the CSD, contractual limitation periods "shall not expire within a period of two years from the time of delivery." 126 Put differently, Article 5(1) Sentence 1 of the CSD relates to the question of when latent defects have to become apparent. This can be referred to as the defect manifestation period or simply warranty period in a narrow sense. Article 5(1) Sentence 2 of the CSD, on the other hand, aims to make sure that available claims do not expire sooner than two years from delivery. ${ }^{127}$ This is called the warranty claim prescription period. The following sections show that some Member States apply, in principle, a single-track system by aligning the start and end dates for both periods. Other Member States differentiate between these two and apply a longer warranty claim prescription period, occasionally in combination with a more flexible warranty period.

For the sake of an easier understanding of the elaborations in the following sections, it is important to note three basic mechanisms or "period designs" that are found in the context of national warranty law schemes. Relevant models incorporate one or more of the following rules:

- Delivery rule: The delivery rule is the most objective solution. Here the respective period would commence at the point of delivery (of the defective product).

- Objective manifestation rule (one could refer to this synonymously as the "detectability rule"): In this case the relevant starting point would be an objectively identifiable point of time, namely the point of time the relevant defect becomes detectable or "objectively apparent" - without requiring the purchaser to actually notice the defect.

125. Council Directive 1999/44/EC, art. 5(1), 1999 O.J. (L 171) 12.

126. $I d$.

127. Id. 
- Subjective manifestation rule: This rule refers to the point of time the purchaser actually detects the defect.

Thus, the permutations of these different models result in a variety of warranty schemes across EU countries.

In 2015, the European Commission presented the Proposal for a Directive on certain aspects concerning contracts for online and other distance sales of goods. ${ }^{128}$ Two years later, the proposal was amended to additionally encompass face-to-face sales. ${ }^{129}$ One of the key aims of the proposal was to introduce a new pan-EU warranty law by repealing the CSD and establishing fully harmonized warranty standards across the EU. ${ }^{130}$ Despite some improvements for consumers (compared to the CSD standards), ${ }^{131}$ the 2017 CSD Proposal constituted a major weakening of protections from an anti-obsolescence point of view. The envisaged switch from minimum to full harmonization meant that Member States that applied more generous provisions - in particular, with respect to the aforementioned time perspective-would have had to lower their standards. ${ }^{132}$ Pursuant to Article 14 of the 2017 CSD Proposal, no warranty remedies would be allowed unless "the lack of conformity becomes apparent within two years as from the relevant time for establishing conformity" (which according to Article 8(1) is generally the time of delivery). ${ }^{133}$ This issue was subject to heavy criticism. The European Economic and Social Committee, for example, voiced its concerns as follows: "The EESC calls for the longer guarantee period applying in certain Member States to be preserved, as otherwise this would be a step

128. Proposal for a Directive of the European Parliament and of the Council on Certain Aspects Concerning Contracts for the Online and Other Distance Sales of Goods, COM (2015) 635 final (Dec. 9, 2015).

129. Proposal for a Directive of the European Parliament and of the Council on Certain Aspects Concerning Contracts for the Sales of Goods, Amending Regulation (EC) No 2006/2004 of the European Parliament and of the Council and Directive 2009/22/EC of the European Parliament and of the Council and Repealing Directive 1999/44/EC of the European Parliament and of the Council, COM (2017) 637 final (Oct. 31, 2017).

130. Article 3 of the 2017 CSD Proposal reads as follows: "Member States shall not maintain or introduce provisions diverging from those laid down in this Directive including more or less stringent provisions to ensure a different level of consumer protection." Id. at art. 3.

131. Most notably, Article 8(3) of the 2017 CSD Proposal extends the reversal of the burden of proof from six months (as prescribed by Article 5(3) of the CSD) to two years. Id. at art. 8(3).

132. Id. art. 14 .

133. Id. 
backwards for consumer rights in these Member States." ${ }^{134}$

The level of harmonization of the proposed directive remained one of the main points of deliberation and negotiation in the legislative process. In May 2019, the European Parliament and the European Council agreed on a compromise and adopted the Directive on certain aspects for the sale of goods (new CSD). Article 4 of the new CSD enshrines a targeted, full harmonization approach - an approach that combines minimum and fully harmonized provisions in one legislative act. ${ }^{135}$ With respect to the present analysis, Article 10(3) of the new CSD is the most important, stipulating that "Member States may maintain or introduce longer time limits." 136 Hence, in keeping with the (at the time of writing this article) current CSD regime, the new CSD does not force purchaser-friendly Member States to drop their longer limitation periods. ${ }^{137}$

\section{2. "Passive" Member States}

A look at the situation in the EU Member States reveals an uneven picture. This is mainly the consequence of the legislative leeway granted under Article 8(2) of the CSD, which allows for more stringent or purchaser-friendly solutions. In a very simplified way, Member States can be categorized into two umbrella groups: "passive" and "active" Member States. This differentiation refers to the way national legislators crafted their warranty schemes with respect to special circumstances (latent defects). The main question in this context is whether a respective jurisdiction applies nuanced warranty schemes that allow for a

134. European Econ. \& Soc. Comm., Opinion of the European Economic and Social Committee on the 'Amended Proposal for a Directive of the European Parliament and of the Council on Certain Aspects Concerning Contracts for the Sales of Goods, Amending Regulation (EC) No 2006/2004 of the European Parliament and of the Council and Directive 2009/22/EC of the European Parliament and of the Council and Repealing Directive 1999/44/EC of the European Parliament and of the Council', at art. 14, COM (2017) 637 final (June 28, 2018).

135. Article 4 of the new CSD states as follows: "Member States shall not maintain or introduce, in their national law, provisions diverging from those laid down in this Directive, including more, or less, stringent provisions to ensure a different level of consumer protection, unless otherwise provided for in this Directive" (emphasis added). Council Directive 2019/771, art. 4, 2019 O.J. (L 136) 28, 41.

136. Council Directive 2019/771, art. 10, 2019 O.J. (L 136) 28, 43.

137. Pursuant to Article 24(1) of the new CSD Member States are required to transpose the directive into national law by July 1,2021 . The national provisions shall apply to contracts concluded on January 1, 2022, at the earliest. Council Directive 2019/771, art. 24(1), 2019 O.J. (L 136) 28, 47. 
differentiating treatment of latent physical defects. While active Member States follow a purchaser-friendly principle and go beyond the minimum level of protection provided by Article 5(1) of the CSD, passive Member States opted to adopt the default rule of Article 5(1) of the CSD.

One example of a passive Member State is Austria. Prior to the implementation of the CSD, the Austrian warranty regime applied a mix of comparatively short warranty and warranty claim prescription periods for physical defects with respect to movable items. In its older version (prior to 2002), Article 933 of the Austrian Civil Code (Allgemeines Bürgerliches Gesetzbuch) enshrined a six-month period that commenced at the delivery of the product. ${ }^{138}$ If no legal action was taken within this six-month period, all warranty claims lapsed. This approach represents a one-tiered solution in which both the defect manifestation period (warranty period) and the warranty claim prescription period were the same length and commenced at the same time: the point of delivery. The implementation of the CSD partially improved the situation from a purchaser's perspective. The sixmonth period was replaced by the two-year minimum mandated by Article 5(1) of the CSD. The commencement event was, however, not changed with respect to the defect manifestation period nor the warranty claim prescription period. Just like its predecessor, the current two year-period of Article 933 of the Austrian Civil Code starts at the delivery of the product and relates to both the warranty period in a narrow sense and the prescription period for bringing claims for breach of warranty.

Article 933 does not differentiate between ordinary or patent defects and latent defects (latent defects are simply defects that manifest themselves at a later point than delivery). Although this solution might be welcome in terms of predictability and legal certainty, it results in injustice from the purchaser's perspective since some latent defects only become apparent subsequent to the expiration of the prescription period. In such cases, the two-year period in combination with the commencement at delivery solution renders legitimate latent defects claims, such as planned obsolescence, ineffective. Austrian law attempts to balance the contractual parties' interests by allowing for a flexible solution in the case of rightsrelated defects or defects that relate to the contractually owed transfer of rights. One classic example can be seen in scenarios in which the purchaser does not obtain legal ownership at the time of the transfer. This defect is a typical example of a latent defect because the failed transfer of

138. Allgemeines Bürgerliches GesetzBuch [ABGB] [Civil Code] $§ 933$, https://ww w.ris.bka.gv.at/GeltendeFassung.wxe?Abfrage $=$ Bundesnormen \&Gesetzesnummer $=1000162$ 2 [https://perma.cc/QG3X-CHTE] (Austria). 
ownership is not detectable at the point of delivery. To remedy this situation, Article 933 Sentence 3 enshrines a generous solution for rightsrelated defects. The warranty claim prescription period commences at the moment the purchaser becomes aware of the non-conformity. The actual point of commencement would not be the delivery, not even the objective detectability of the defect, but the subjectively determined point of time when the purchaser becomes aware of the non-conformity. This solution is called the subjective manifestation rule.

Over the years, case law has evolved to recognize that similar fairness concerns do not only occur with respect to rights-related defects but can also arise in certain cases of physical defects. For a small group of latent physical defects, the courts decided to apply a comparable mechanism, but switched to an objective manifestation rule in which the prescription period starts when the defect becomes objectively detectable. The rationale for extending the prescription period beyond the two years provided in Article 933 is the assumption that contractual parties tacitly agree on postponing the commencement of the prescription period when they contractually stipulate product specifications whose fulfillment cannot be verified in due time. ${ }^{139}$

Given the above limitation periods, can Austrian warranty law be used in cases of planned obsolescence? In terms of detectability, planned obsolescence resembles latent physical defects not detectable at the point of delivery. The big issue in the case of planned obsolescence, however, is that in the vast majority of cases relevant defects do not relate to agreed specifications, but merely to reasonably expected product lifetimes. In the Austrian literature, the question of whether it is permissible to apply a subjective or objective manifestation rule in planned obsolescence situations has not been conclusively answered. In more recent years, the courts have been more receptive to purchaser-friendly arguments. ${ }^{140}$ Case law, however, has failed to expressly recognize the application of the manifestation rule to cases of planned obsolescence.

Based on current case law, Austrian law falls under the category of passive Member States. It has yet to apply a more nuanced approach that would allow for the application of a suitable manifestation rule in cases of planned obsolescence. Austria is not alone in this respect. It is joined by other Member States that include Bulgaria, Croatia, Cyprus, Germany, Greece, Latvia, Lithuania, and Malta. ${ }^{141}$ All of them recognize the two-

139. For more details on this issue, see DiMatteo \& Wrbka, supra note 45 , at 71.

140. Id. at $72-73$ (providing further references).

141. ECC-NET, supra note 121, at 101-03. 
year-delivery rule and have avoided recognizing the need for a differentiating regime in cases of planned obsolescence. Some other Member States such as the Czech Republic, ${ }^{142}$ Denmark, ${ }^{143}$ Estonia, ${ }^{144}$ Italy, ${ }^{145}$ Portugal,${ }^{146}$ Slovakia, ${ }^{147}$ Slovenia, ${ }^{148}$ and Spain ${ }^{149}$ are mostly passive in their approach to viewing planned obsolescence as a product defect, although they adopt a slightly more purchaser-friendly position, which differentiates between defect manifestation and warranty claim prescription periods. Regardless of this differentiation, however, these Member States are best classified as "passive" Member States because they do not provide for a more generous solution to cover cases of latent defects, such as cases of planned obsolescence that manifest later than a reasonable time.

\section{3. "Active" Member States}

The second group of Member States includes jurisdictions that assume a purchaser-friendly attitude. Examples include Belgium, Finland, France, arguably Hungary, ${ }^{150}$ Ireland, Luxembourg, the Netherlands, Romania, ${ }^{151}$

142. Id., at 101-03 (providing a prescription period of three years calculated from the point the consumer asked for correction of the defect).

143. Id. (providing a prescription period of three years calculated from the detectability of the defect).

144. Id. (providing a prescription period of three years calculated from the point of delivery).

145. Id. (providing a prescription period of 26 months calculated from the point of delivery).

146. Id. (providing a prescription period of two years calculated from notification to the seller of the defect).

147. Id. (providing a prescription period of three years calculated from notification to the seller of the defect).

148. Id. (providing a prescription period of two years calculated from notification to the seller of the defect).

149. Id. (providing a prescription period of three years calculated from the point of delivery).

150. In B2C cases, Hungary, in principle, applies a strict two-year period as seen in the cases of the passive Member States. 2013. évi V. törvény a Polgári Törvénykönyvröl (Act V of 2013 on the Civil Code) $\S 6: 163$ (2) (Hung.). However, Section 6:24(1) of the Hungarian Civil Code provides that the prescription period is suspended if the claimant, "for an excusable reason," is not in a position to enforce a claim. 2013. évi V. törvény a Polgári Törvénykönyvröl (Act V of 2013 on the Civil Code) § 6:24(1) (Hung.), tdziegler.wordpress. com/2014/06/25/the-text-of-the-new-civil-code-of-hungary-in-english/ [https://perma.cc/QL 8T-EVB9]. This, as pointed out by the Consumer Law Compendium, with respect to a similar solution applied by prior versions of the Hungarian Civil Code, can be understood to apply in cases "where the lack of conformity, due to its character or the nature of the goods, does not appear until later." UniversitÄt BIELEFELD, supra note 123, at 701 . In a 
Sweden, and the United Kingdom. Taking a purchaser-friendly approach can, in principle, take shape in two different ways. Member States may apply a system that goes significantly beyond the framework enshrined in Article 5(1) of the CSD. Alternatively, they may provide for a more nuanced warranty scheme or two different regimes: a general warranty regime and a more specific scheme based on the CSD that usually functions as an alternative mechanism in B2C cases.

Arguably the simplest strategy to maximize the potential of warranty law is to introduce longer or extended warranty periods. This approach can be found, for example, in Ireland and the United Kingdom, which adopted six-year warranty periods, ${ }^{152}$ and Sweden with a three-year period. Belgium has a prescription period of ten years, ${ }^{153}$ limited to latent defects as defined by Article 1641 of the Belgian Civil Code. ${ }^{154}$ All of these extended warranty period schemes were in place before the implementation of the CSD. Although some of these extended warranty periods were not originally directed at cases of latent defects, they should be of considerable help in attempts to regulate planned obsolescence. ${ }^{155}$

Some of the active Member States opted for more complex (or at least multi-track) warranty schemes that would usually be available as alternative mechanisms in cases of latent defects. In these instances,

comparable vein is ECC-NET, supra note 121 , at 41 , which, however, explicitly refers to the warranty claim prescription period (in the sense of article 5(1), sentence 2 of the CSD) and not to the broader concept of warranty periods that encompass defect manifestation periods as well. Following the understanding of the Consumer Law Compendium, Hungary might be grouped under the category of active Member States, although pertinent case law is, to the best of our knowledge, still pending with respect to planned obsolescence.

151. For remarks on the possible extension of prescription periods beyond the statutory two-year period in the case of hidden defects under Romanian law, see EUROPEAN COMM'N, Consumer Market Study on the Functioning of Legal and Commercial Guarantees FOR CONSUMERS IN THE EU - COUNTRY Fiche: ROMANiA 7 (2015); EUROPEAN COMm'N, Consumer Market Study on the Functioning of Legal and Commercial Guarantees FOR CONSUMERS IN THE EU - FINAL REPORT 21 (2015).

152. Scotland, however, provides for a five-year period.

153. Code Civil [C.Civ.] art. 2262(B) (Belg.).

154. Note that, for other cases of physical defects, the purchaser can only refer to the narrower warranty scheme of Articles 1649bis-1649octies of the Belgian Civil Code that, in principle, implemented the CSD regime. For details, see EUROPEAN COMM'N, CONSUMER Market Study on the Functioning of Legal and Commercial Guarantees fOR CONSUmers IN the EU - COUnTRY Fiche: Belgium 8 (2015); Gewährleistungsrecht Belgien, Ger. Trade \& Inv. 2 (Feb. 10, 2015), www.gtai.de/GTAI/Navigation/DE/Trade/Re cht-Zoll/Wirtschafts-und-steuerrecht/Produkte/Dienstleistungsrecht/Portal21/Laender/Belgie $\mathrm{n} /$ Rechtsrahmen/Zivilrecht/gewaehrleistunsgrecht.html [https://perma.cc/Z2PD-GP5P].

155. This understanding rests on the assumption that respective cases of not reaching reasonably expected product lifetimes constitute warranty-relevant, physical defects. 
purchasers could (in B2C scenarios) choose between the different schemes. France, in its transposition of the CSD into French law, introduced a B2C warranty regime in the French Consumer Code (Code de la Consommation). ${ }^{156}$ The regime, in principle, follows the model of the CSD, but goes beyond it by making use of the legislative leeway granted by the Directive. For example, the Consumer Code increased the period of the reversal of the burden of proof from six months (as prescribed by the Article 5(3) of the CSD) to two years for new products. ${ }^{157}$ Should a defect become apparent during this period, it is the seller who has the burden of proving that the defect did not exist at the time of delivery. Given the importance of the burden of proof in delayed claims, the reversal of the burden of proof to the defendant increases the chances of success of claims in cases of planned obsolescence.

A greater impact on the problem of planned obsolescence is seen in the revision of French law relating to latent defects - the garantie des vices caches (warranty for latent defects). This scheme is enshrined in Articles 1625 et seq. of the French Civil Code, with a group of key provisions found in Articles 1641 to 1649 of the French Civil Code. Under the basic rule of Article 1641, the seller must warrant that goods are free from latent defects that make the purchased goods unfit for their intended purpose or generally impair the purchaser's reasonable expectation of usability. ${ }^{158}$ If a physical defect can be classified as a latent defect in the meaning of Article 1641, purchasers may be in a better position to win a claim of planned obsolescence than under the French Consumer Code. Remedies under the Civil Code are limited to the right to claim price reduction (action estimatoire) and the right to return the good (action rédhibitoire), but in terms of the time aspect, the solution of Article 1648 of the French Civil Code is significantly more purchaser-friendly than its Consumer Code counterpart. As is the case in the objective manifestation rule examples discussed further below, it does not provide for a warranty period in the narrow sense, at least not explicitly. Instead, the French Civil Code

156. Code de la Consommation [Consumer Code] art. L211-1 et seq. (Fr.) (introducing more specific rules in Art. L211-4 et seq.).

157. Id. art. L217-17 et seq. For more detail on this topic, see EUROPEAN COMM'N, Consumer Market Study on the Functioning of Legal and Commercial GuaranteEs FOR CONSUMERS IN THE EU - COUNTRY FICHE: FRANCE 6 (2015).

158. CODE CIVIL [C. CIV.] [CIVIL CODE] art. 1641 (Fr.), www.legifrance.gouv.fr/content/d ownload/1950/13681/version/3/file/Code22.pdf [https://perma.cc/59SM-54V7] ("A seller is bound to a warranty on account of the latent defects of the thing sold which render it unfit for the use for which it was intended, or which so impair that use that the buyer would not have acquired it, or would only have given a lesser price for it, had he known of them."). 
mechanism enshrines a two-year prescription period that commences at the "point of discovery" of the latent defect by the purchaser, adopting the subjective manifestation rule. ${ }^{159}$ As indicated earlier, this solution might be particularly helpful in cases of planned obsolescence. For the sake of differentiation between non-B2C and $\mathrm{B} 2 \mathrm{C}$ scenarios, it should be noted that Article 1643 of the French Civil Code gives the seller the right to contractually exclude liability for latent defects. Case law, however, holds that the exclusion is not enforceable where the seller has substantially more bargaining power than the purchaser. ${ }^{160}$

France is not the only Member State that has adopted the manifestation rule approach. Statutory prescription models for physical defects that differ from the general delivery rule can be found in other Member States. One example is the Luxembourg Civil Code, which was heavily influenced by the French Civil Code. The prescription model of Article 1648(1) and (2) of the Luxembourg Civil Code adopts the approach of Article 1648 of the French Civil Code, with its purchaser-friendly rule for latent defects in consumer transactions. ${ }^{161}$ However, the Luxembourg Civil Code slightly differs from the French Civil Code by mandating that the purchaser inform the seller of a defect "within a short time from the moment the purchaser found out about the defect or should have been able to find out." ${ }^{162}$ Article 1648(1) of the Luxembourg Civil Code incorporates an objective manifestation rule. Article 1648(2) adds that the right to file

159. The applicable, absolute statutory time limitation appears to be disputed. Strong arguments point to the application of a twenty-year rule pursuant to Article 2232 of the French Civil Code. CodE CIVIL [C.CIV.] [CIVIL CODE] art. 2232 (Fr.). In this vein, see the information provided by Jonas Knetsch on Dec. 13, 2018 (information on file with authors); Florian Endrös, Responsabilité civile - Eine Reise durch den französischen Haftpflichtmarkt, DOCPLAYER 15 (June 15, 2016), https://docplayer.org/43673923-Responsa bilite-civile.html [https://perma.cc/LYY4-CVR9]. Others argue for the application of a shorter period of five years. In this vein, see the information provided by Alexandre Talbot on Dec. 2, 2018 (information on file with authors).

160. For a more recent commentary, see Gewährleistungsrecht Frankreich, GER. TRADE \& INV. 2 (Nov. 5, 2018), www.gtai.de/GTAI/Navigation/DE/Trade/Recht-Zoll/Wirtschafts-u nd-steuerrecht/Produkte/Dienstleistungsrecht/Portal21/Laender/Frankreich/Rechtsrahmen/Zi vilrecht/gewaehrleistunsgrecht.html [https://perma.cc/6MCM-RFWJ]. For relevant case law, see Cour de cassation [Cass.] [supreme court for judicial matters] 3e civ., Jan. 22, 1974, Bull. civ. III, No. $72-14014$ (Fr.); Cour de cassation [Cass.] [supreme court for judicial matters] 1e civ., July 1, 2010, Bull. civ. I, No. 09-16114 (Fr.).

161. On the national implementation, see European COMM'N, CONSUMER MARKeT Study on the Functioning of LeGAL AND COMMERCIAL GuARANTEES FOR CONSUMERS IN THE EU - COUNTRY FiCHE: LuXEMBOURG (2015).

162. Code Civil [Civil CoDE] art. 1648(1) (Luxembourg) (translation by Stefan Wrbka). For further details, see ECC-NET, supra note 121, at 47-48. 
an action must be within "one year calculated from the point of notification" of the defect. ${ }^{163}$

Similarly, Article 7:23 of the Dutch Civil Code (Burgerlijk Wetboek) adopts an objective manifestation rule. Pursuant to Article 7:23(1), purchasers "can no longer claim that the supplied object is not in conformity with the sale agreement if they have not reported the lack of conformity to the seller with convenient speed after they have discovered or reasonably should have discovered it." 164 It adds that two months is considered as fulfilling this timely notification requirement. Under the condition that the purchaser notifies the seller in due time, a two-year prescription period for filing a possible claim would commence from the time of notification. ${ }^{165}$ Studies point out that the Dutch system is particularly suitable to cover incidents of shortened product lifetimes because it puts a greater emphasis on the importance of lifespan. ${ }^{166}$ Products that do not reach a reasonably expected lifetime are considered to be defective. The combination of the flexible warranty claim prescription period and the recognition of shortened product life spans as defects benefits purchasers in cases of planned obsolescence.

Finland possesses certain similarities to these two approaches. The Finnish warranty regime enshrined in the Finnish Sale of Goods Act ${ }^{167}$ is based on a general defect definition comparable to the definition introduced by the CSD. Quite similar to the Luxembourg solution, the Finnish scheme simply provides a reasonable notification period. Pursuant to Article 32 of the Finnish Sale of Goods Act, it is calculated from the point of time the purchaser should have become aware of the defect without giving a hint as to what "reasonable" means. The European Consumer Centres Network (ECC-Net) characterizes the Finnish system as incorporating a "reasonably expectable lifespan" assessment tool, under which the Finnish Consumer Disputes Board has the competence to issue (non-binding) lifespan

163. Code Civil [Civil Code] art. 1648(2) (Luxembourg)

164. Dutch Civil Code, Dutch CIv. L. art. 7:23(1), www.dutchcivillaw.com/civilcodebo ok077.htm [https://perma.cc/Y7XC-PXH4].

165. Id. at art. 7:23(2) ("Rights of action (legal claims) and defences, grounded on facts which would justify the conception that the supplied object is not in conformity with the agreement, become prescribed on the expiry of two years after the report has been made in accordance with the first paragraph.").

166. See, e.g., ECC-NET, supra note 121, at 17 (comparing guarantee and warranty laws in EU member states, Iceland, and Norway); European COMm'N, CONSUMER Market Study on the Functioning of Legal AND COMMERCial GuARANTEES For CONSUMERS IN THE EU - FINAL REPORT 22 (2015) (evaluating the legal guarantees of different regulatory environments in the EU).

167. Sale of Goods Act, art. 17 et seq. (Act No. 355/1987) (Fin.). 
standard ranges for different product categories. ${ }^{168}$ If a product falls significantly short of the applicable target, a warranty-relevant (durability) defect, as in the case of the Netherlands, is assumed. It has to be added that the possibility to file a warranty claim itself lapses after three years from the objective detectability of the defect. ${ }^{169}$ The next section further analyzes the potential and availability of warranty law in cases of planned obsolescence, as well as reviewing the law of countries from jurisdictions outside of Europe. ${ }^{170}$

\section{Other Jurisdictions}

This section analyzes the law of a broader set of countries to determine whether cases of planned obsolescence can be, in principle, recognized as product defects under these laws. The analysis focuses on the issues of the availability of warranty law, liability under warranty law, remedies offered in cases of violations of warranty law, and the impact of time limitations on the exercise of claims and obtaining remedial redress.

\section{Availability of Warranty Law}

Earlier, planned obsolescence was differentiated between three possible obsolescence scenarios. It was determined that it was Packard's obsolescence of quality category that is of particular relevance in this respect. The reason for this is that this dimension of obsolescence allows for a plausible argument that products that do not reach an objectively expected durability level constitute warranty-relevant defects.

A look at the examined schemes confirmed the assumption that warranty regimes are able to capture planned obsolescence when applying objective parameters to determine whether a product shows warrantyrelevant defects. In the vast majority of cases, this is the instance if products do not meet generally expected, objective quality standards, as seen in India ${ }^{171}$ and South Korea, ${ }^{172}$ or do not possess generally required or

168. ECC-NET, supra note 121 , at 17.

169. This solution follows the general prescription rule for contract-based claims enshrined in Articles 5 and 7 of the Finnish Act on limitations on debts. Finnish law does not contain a specific rule for warranty claims.

170. The list includes the following countries and jurisdictions: Armenia, Australia, Brazil, Cambodia, Canada, Chile, China, Hong Kong, Iceland, India, Indonesia, Japan, Kosovo, Mongolia, Norway, the Philippines, Russia, South Africa, South Korea, Switzerland, Ukraine and Vietnam.

171. Section 2(1)(f) of the Indian Consumer Protection Act defines the term defect 
necessary attributes, as in Belarus, ${ }^{173}$ Brazil, ${ }^{174}$ Cambodia, ${ }^{175}$ Canada, ${ }^{176}$ Chile, ${ }^{177}$ China, ${ }^{178}$ Indonesia, ${ }^{179}$ Kosovo, ${ }^{180}$ Mongolia (in a non-B2C

broadly as "any fault, imperfection or shortcoming in the quality, quantity, potency, purity or standard which is required to be maintained by or under ... under any contract, express or implied ... in relation to any goods." The Indian Consumer Protection Act, No. 68 of 1986, INDIA CODE (1986), vol. 2. Case law has added a "reasonable expectation" criterion in the sense that physical defects would have to be assumed in cases in which a reasonable purchaser would not have entered a contract if the true product quality would have been known by the purchaser (information provided by Pankaj Singla on Nov. 28, 2018, referring to case law such as the Delhi High Court in Jaswant Rai v. Abnash Kaur on Oct. 3, 1973, and the Bombay High Court in Lallubhai Rupchand v. Mohanlal Sakarchand on Jan. 22, 1934) (information on file with authors).

172. The South Korean warranty regime of the South Korean Civil Code rests generally on rights-related defects as the key "defect model" and applies the rules mutatis mutandis to material or physical defects. Minbeob [Civil Act], Act No. 8720, Dec. 21, 2007, art. 580 (S. Kor.). Case law has developed the general rule that physical defects are cases in which the good does not meet objective quality standards that can be commonly expected (information provided by Jae J. Kim on Nov. 28, 2018, referring to pertinent case law that includes the South Korean Supreme Court Decision, 4290minsang762, of Feb. 13, 1958, and South Korean Supreme Court Decision, 98da18506, of Jan. 8, 2000) (information on file with authors).

173. Quality of Good, Civil Code, LAw No. 218-Z, 439 (1998) (Belr.).

174. Decreto No. 3.071, de 1 de Janeiro de 1916, Diário Oficial da União [D.O.U.] de 5.1.1916 (Braz.); Decreto No. 8.078, de 11 de Setembro de 1990, DiÁRIO OFICIAL DA UNIÃo [D.O.U.] de 12.9.1990 (Braz.).

175. Obligation to Deliver Non-Defective Object, CIvil CoDE, para. 539(2)(c)-(d) (2007) (Cambodia).

176. See, e.g., Implied Conditions as to Quality or Fitness, R.S.O. 1990, c S.1, s. 15(3) (Can.) (providing an exception to permit an implied warranty or condition when annexed by the usage of trade).

177. Law No. 7.613 art. 1858, Septiembre 21, 1995, Código Civil [CóD. Civ.] (Chile); Law No. 19.496 art. 20(f), Febrero 7, 1997, Código de ProteCción al Consumidor (Chile).

178. Articles 61 and 62 of the Chinese Contract Law mention the terms "relevant usage" and "customary standard" as potential criteria to assess the contractual conformity of a product. Zhōnghuá rénmín gònghéguó de hétóng fã (中華人民共和國的合同法) [Contract Law] (promulgated by the Second Session of the Ninth Nat'l People's Cong., Mar. 15, 1999) at art. 61-62 (China), www.wipo.int/edocs/lexdocs/laws/en/cn/cn137en.pdf [https://p erma.cc/VY9N-6Y3J].

179. "The seller shall be bound to warrant against hidden defects of the sold assets, which would render them unsuitable for the intended use, or which would reduce the use in such manner, that if the buyer had been aware of such defects, he would not have purchased those assets, or would have purchased them at a lower price." Concerning the Obligations of the Seller, CiviL CODE, S.NO. 23, 1504 (1847) (Indon.).

180. "A defect shall be deemed material if the thing does not have the attributes necessary for the customary use or marketing of the thing." When Material Defect is Involved, Law on Obligational Relationships, Law No. 04/L-077, 462(1), 2012 (Kos.). 
context), ${ }^{181}$ the Philippines, ${ }^{182}$ Russia, ${ }^{183}$ Serbia, ${ }^{184}$ Switzerland, ${ }^{185}$ and Ukraine. ${ }^{186}$ Some jurisdictions, however, go one step further by making explicit reference to durability in their respective laws. In these cases, the actual lifetime of a product or durability is explicitly listed as one factor that can be applied to evaluate whether, from a warranty perspective, the quality of the product is in conformity with the contract or not. ${ }^{187}$

181. Article 251(2) of the Mongolian Civil Code requires that the good be "physical nondeficient" for cases in which the parties do not explicitly agree on a specific quality. In these scenarios, the good must be of a quality that allows for the purchaser to use it for the purpose stated in the contract. The provision does not clarify if this is to be understood as a general implied warranty (that would apply even in cases where the purpose of intended use is not explicitly stated in the contract). Physical Deficiency of Sold Property, CIVIL CoDE [C. CIV.], 251(2) (2002) (Mong.).

182. Articles 1561 and 1562 of the Filipino Civil Code discuss the term "hidden defect" and link it inter alia to the purpose for which the purchaser acquired the product. CIVIL CoDE, $\S \S 1561-62$, Rep. Act 386, as amended (Phil.).

183. "In the absence of quality terms in the contract of sale the seller shall be obliged to hand over to the customs goods suitable for the purposes for which goods of this sort are usually used." GrazhDANSKII KoDEKS Rossisskoi FEDERATSII [GK RF] [Civil Code] art. 469(2) (Russ.).

184. When Do Substantive Defects Exist, Zakon O Obligacionim Odnosima, No. 29/78, 479 (1978) (Serb.); Passing of Risk, Law on Consumer Protection, 50 (2014) (Serb.).

185. "The seller is liable to the buyer . . . for any defects that would materially ... negate or substantially reduce the value of the object or its fitness for the designated purpose." Obligationenrecht, Code Des obligations, Codice Delle obligazioni [Code of Obligations], Mar. 30, 1911, art. 197(1) (Switz.).

186. Quality of Goods, CiviL CoDE, art. 673(2) (2017) (Ukr.).

187. Examples include: Article 486(1) of the Armenian Civil Code, which clarifies that a good must be usable for a reasonable period of time, Guaranty of Quality of the Goods, Civil Code of the Republic of Armenia, HO-239, 486(1) (1998) (Arm.); Section 54(2)(e) of the Australian Consumer Law, which states that "[g]oods are of acceptable quality if they are as durable as a reasonable consumer fully acquainted with the state and condition of the goods (including any hidden defects of the goods), would regard as acceptable," Australian Consumer Law 2010 (Cth) s 54(2)(e) (Austl.); Chapter 410, Section 18(c) of the British Columbia Sale of Goods Act, which states that "there is an implied condition that the goods will be durable for a reasonable period of time having regard to the use to which they would normally be put and to all the surrounding circumstances," Sale of Goods Act, R.S.B.C. 1996, c 410, s. 18(c) (Can.); Chapter P-40.1, Section 38 of the Consumer Protection Act of Quebec, which states that "[g]oods forming the object of a contract must be durable in normal use for a reasonable length of time, having regard to their price, the terms of the contract and the conditions of their use," Consumer Protection Act of Quebec, R.S.O. 1978, c. P-40.1, s. 38 (Can.); Section 16(2) in combination with the definition of "merchantable quality" under Section 2(5) of the Hong Kong Sale of Goods Ordinance (Chapter 26), Sale of Goods Ordinance, (1977) Cap. 1, §§ 2(5), 16(2) (H.K.); Article 5(2) of the Mongolian Law on Consumer Protection, which uses the term "durability period," Consumer Rights to Receive Quality and Safe Goods, Works and Services, On Consumer Protection, 5(2) (2003) (Mong.); and Section 55(2)(c) of the South African Consumer Protection Act, which reads 


\section{Liability Under Warranty Law}

The question of which parties are liable under the respective warranty schemes does not have a direct effect on the relevance of warranty law in the context of planned obsolescence. The issue nevertheless deserves a brief comment because the range of possibly liable parties may have an effect on the actual chances of obtaining remedies. Generally, buyers' chances of bringing successful claims increase as the scope of potentially liable parties widens.

The majority of examined jurisdictions focus on direct liability to the seller of the defective product. ${ }^{188}$ Examples include Brazil ${ }^{189}$ Canada (with exceptions),${ }^{190}$ Chile, ${ }^{191}$ China, ${ }^{192}$ Hong Kong, ${ }^{193}$ Iceland, ${ }^{194}$ Indonesia, ${ }^{195}$

"every consumer has a right to receive goods that will be useable and durable for a reasonable period of time, having regard to the use to which they would normally be put and to all the surrounding circumstances of their supply." Consumer Protection Act of $2009 \S$ 55(2)(c) (S. Afr.).

188. See further Consumer Protection Act of 2009 § 56(2) (S. Afr.) (allowing the consumer to return the good to the supplier). The supplier, in this case, has (by way of interpretation) to be understood as the consumer's contractual partner. $I d$. at $\S 56(2)(\mathrm{b})$.

189. See Decreto No. 8.078, supra note 174 (noting that although the term "supplier" is broadly defined by Article 3 to encompass producers, Article 21, for example, clearly differentiates between suppliers - liable parties in a warranty law context - and producers. "Suppliers" in a warranty law context hence have to be understood as sellers of defective products.).

190. The Canadian province of Quebec provides for direct producers' liability in certain B2C situations. In this sense Chapter P-40.1, Section 38 of the Consumer Protection Act of Quebec stipulates as follows: "A consumer who has entered into a contract with a merchant is entitled to exercise directly against the merchant or the manufacturer a recourse based on a latent defect in the goods forming the object of the contract, unless the consumer could have discovered the defect by an ordinary examination." Consumer Protection Act of Quebec, C.Q.L.R. 1971, c P-40.1, sec. 38 (Can.). In non-B2C cases, Article 1726 of the Quebec Civil Code limits the range of liable parties to the seller: "The seller is bound to warrant the buyer that the property and its accessories are, at the time of the sale, free of latent defects which render it unfit for the use for which it was intended or which so diminish its usefulness that the buyer would not have bought it or paid so high a price if he had been aware of them." Civil Code of Quebec, S.Q. 1991, c 64, art. 1726 (Can.).

191. CoD. Civ. art. 1837, Mayo 16, 1997 (Chile). See also Law No. 19496 art. 21, Establece Normas Sobre Protección de los Derechos de los Consumidores, Febrero 7, 1997 (Chile) (giving the purchaser (in a B2C situation) the option to ask for direct repair by the producer in case the purchaser chooses repair).

192. Chinese Product Quality Law, art. 40, Sept. 1, 1993.

193. Hong Kong Sale of Goods Ordinance, (1896) O.H.K., §55.

194. Consumer Sales Act sec. 26 (Act No. 48/2003) (Ice.). Section 27(3) of the Icelandic Consumer Sales Act follows the notification system applied in Norway.

195. CIVIL CODE, art. 1491, 1504 (S.NO. 23) (Indon.). Article 25 of the Indonesian Consumer Protection Law obliges producers inter alia to provide spare parts and after sales 
Japan ${ }^{196}$ Norway, ${ }^{197}$ the Philippines, ${ }^{198}$ Serbia, ${ }^{199}$ South Korea,${ }^{200}$ Switzerland, ${ }^{201}$ and Vietnam. ${ }^{202}$ A second, smaller group of jurisdictions broadens the scope towards additionally liable parties, in most cases towards the producer of the defective good or direct producer's liability. Examples include Australia ${ }^{203}$ and Kosovo. ${ }^{204}$

In other cases, the scope of potentially liable parties differs depending on the circumstances. Article 475(1) of the Russian Civil Code, for example, limits - as a general rule - the range of directly liable parties to the sellers of defective products. With respect to $\mathrm{B} 2 \mathrm{C}$ transactions, the

facilities for goods that are useable for more than one year in a B2C context. This, however, does not constitute a general, mandatory producer's warranty, but merely introduces an inaccurately defined, limited "warranty" with respect to spare parts and after sales facilities. Consumer Protection Law, art. 25 (Act No. 8/1999) (Indon.).

196. MINPŌ [MINPŌ] [CIV. C] art. 560 et seq. (Japan) (both in the old and new versions).

197. Norwegian Sale of Goods Act 1988, sec. 26 (Nor.). Section 27 of the Norwegian Sale of Goods Act adds a "timely notification rule" under which the purchaser must inform the seller about the defect in due time. Note, however, that Section 27(3) of the Norwegian Consumer Sales Act allows for a complaint to a third party, if this is agreed with the seller.

198. Civil Code, Art. 1561 et seq. (Phil.) (limiting liability to the seller); Civil Code, Art. 68 (Phil.) (broadening the range to further parties, most notably to producers in the case of voluntary express (but not implied) warranties in B2C scenarios). However, it should be noted that broadening the range of potential parties in cases of (voluntary) express warranties is not unique. Actually, all of the examined jurisdictions allow for comparable additional warranties issued by third parties (including the producer).

199. Pursuant to the basic rule of Article 478 of the Serbian Law of Obligations warranty claims can, in principle, be filed only against the seller. With respect to certain product categories (listed in Article 501 of the Serbian Law of Obligation) the purchaser could alternatively address the producer of the defective good (information provided by Mateja Durovic on Dec. 3, 2018) (information on file with authors).

200. Minbeob [Civil Act], Act No. 8720, Dec. 21, 2007, art. 568 et seq. (S. Kor.).

201. Obligationenrecht, Code Des Obligations, Code Delle Obligazioni [Code of Obligations], March 30, 1911, art. 197 (Switz.).

202. Civil Code of Vietnam, art. 445 (No. 33-2005-QH11/2001) (Viet.). The Vietnamese Law on the Protection of Consumer Rights broadens the scope of parties liable for defective products in certain situations to third parties (producers and direct suppliers). Law on Protection of Consumer Rights, art. 22, 23 (No. 59/2010/QH12) (Viet.), vietnamlawmagazine.vn/law-on-protection-of-consumer-rights-4688.html [https://perma.cc /TUH2-6H2G]. However, these situations arguably relate to products liability cases. Article 21 of the Vietnamese Law on the Protection of Consumer Rights states that "Warranty shall be provided on goods... as agreed by parties or required by law." The latter one ("law") would refer to Article 445 of the Vietnamese Civil Code, which limits the scope of liable parties for (ordinary) warranty law cases to sellers.

203. See Australian Consumer Law 2010 (Cth) s 259 et seq. (Austl.) (indicating the liability of suppliers (in this context understood as direct sellers) and producers and their special liability).

204. Law on Obligational Relationships, art. 485 (Law No. 04/L-077) (Kos.). 
Russian Consumer Protection Law, however, broadens the list. Most notably, Article 18(3) of that law allows for direct repair or replacement claims against the producer of the defective product. The situation in Armenia basically resembles this non-B2C-B2C divide. Article 491 of the Armenian Civil Code allows for claims only against the seller. Article 16 of the Armenian Consumer Rights Protection Act, however, allows for alternative claims against the producer of defective products in certain B2C scenarios. ${ }^{205}$ Belarus and Mongolia join this group of jurisdictions that broaden the range of possibly liable parties in $\mathrm{B} 2 \mathrm{C}$ transactions beyond the general rule that limits liability to direct sellers. ${ }^{206}$ The Indian Consumer Protection Act broadens the scope of potentially liable parties since the relevant term "trader" explicitly includes producers. ${ }^{207}$ The jurisdictions that recognize direct producer's liability include Ukraine. The Ukrainian Civil Code again focuses on sellers' liability but allows for producer liability pursuant to Article 678(3) of the Ukrainian Civil Code with respect to repair and replacement claims.

\section{Possible Remedies}

Some jurisdictions apply a mix of remedies-including repair, replacement, price reduction and rescission - that principally resembles the two-tiered EU scheme of Article 3 of the CSD. Examples of countries with an explicit, two-level approach (repair and replacement as primary remedies; price reduction and rescission as secondary remedies) include Japan, ${ }^{208}$ Kosovo, ${ }^{209}$ Serbia, ${ }^{210}$ and Vietnam. ${ }^{211}$ Iceland and Norway do not

205. Possible claims against the producer under the Armenian Consumer Rights Protection Act are principally limited to repair or replacement (information provided by Suren Gomtsyan on Nov. 17, 2018) (on file with authors).

206. Civil Code, Law No. 218-Z, 445(1) (1998) (Belr.) (limiting liability to the seller); Article 15 of the Belarusian Consumer Protection Law. Article 253 of the Mongolian Civil Code limits the seller's liability, but Article 5 et seq. of the Mongolian Law on Consumer Protection provides an extension of the warranty liability to producers. It should be noted though that non-fault-based warranty remedies can only be exercised against the seller not the producer under Article 6(1) of Mongolian Law on Consumer Protection.

207. "“[T]rader' in relation to any goods ... includes the manufacturer thereof." Indian Consumer Protection Act, sec. 2(1)(g), INDIA CodE (1986).

208. This case law developed rule is - with effect of Apr. 1,2020 - enshrined in Articles 562 et seq. of the revised Japanese Civil Code. Minpō [MinPō] [CIv. C] art. 562 et seq. (Japan).

209. Law on Obligational Relationships, art. 487 (Law No. 04/L-077) (Kos.).

210. Serbian law differentiates between B2C and non-B2C situations in this context. The remedial system in $\mathrm{B} 2 \mathrm{C}$ cases follows the EU example and differentiates between the primary remedies of repair and replacement and the secondary remedies of price reduction 
explicitly apply a two-tiered approach, but they arrive at a comparable remedial scheme. The national laws do not give repair and replacement direct priority, but they allow the seller of the defective product to remedy the defect by way of repair or replacement if done within a reasonably short period of time, even if the purchaser wants a different remedy. ${ }^{212}$

Article 445 of the Belarusian Civil Code enshrines a two-tiered solution as well but draws a different line between the remedies. Pursuant to the first paragraph of said provision, the purchaser may-similar to Article 3(3) of the CSD - choose freely between price reduction and repair. Article 445(2) introduces replacement and rescission as secondary remedies for those situations in which the primary remedies are not effective. In a comparable vein, Article 678(1) of the Ukrainian Civil Code places the emphasis on price reduction and repair, but Article 678(2) allows for rescission and replacement in cases of a "significant violation," which the law defines primarily as non-repairable or recurrent defects. ${ }^{213}$

In a number of jurisdictions, the law differentiates between varieties of possible claims without providing for a comparable, hierarchical structure of remedies. Examples include the following: (1) Armenia (repair, replacement, price reduction, rescission), ${ }^{214}$ (2) Brazil (price

and rescission (LAw on Consumer Protection, art. 52 (Serb.)). Article 488 of the Serbian Civil Code, on the other hand, put price reduction at the same level with repair and replacement primary remedies) and limits the category of secondary remedies to rescission. LAW OF CONTRACTS AND TORTS, art. 488 (Serb.) (information provided by Mateja Durovic on Dec. 3, 2018; on file with authors).

211. Article 448 of the Vietnamese Civil Code gives priority (only) to repair: "A purchaser has the right to require the seller to complete the repairs within a time limit agreed by the parties or within a reasonable time. If the seller is not able to make or complete the repairs within such time, the purchaser has the right to demand a price reduction or replacement of the defective object with another object, or it has the right to return the object in exchange for a refund." Civil CODE OF VIETNAM, art. 448 (No. 33-2005QH11/2001) (Viet.), www.wipo.int/wipolex/en/text.jsp?file_id=445413 [https://perma.cc/T P9Q-EVSE].

212. Consumer Sales Act, sec. 29(3) (Act No. 48/2003) (Ice.); Norwegian Sale of Goods Act 1988, sec. 29(3) (Nor.).

213. Civil CODE OF UKRAINE, art. 678(2) (Ukr.), www.teplydim.com.ua/static/storage/fil esfiles/Civil Code_Eng.pdf [https://perma.cc/2M33-JADF].

214. This applies to B2C cases; Article 16 of the Armenian Consumer Rights Protection Act gives the purchaser the right to choose between the remedies. About Consumer Protection, art. 16, Law of the Republic of Armenia of July 20, 2001 (No. ZR-197) (Arm.). In non-B2C cases, Article 491 of the Armenian Civil Code would apply. In this case, the purchaser can, as a first step, choose between repair, replacement and price reduction and, as a second step (or alternatively in cases in which the defect is more serious), can rescind the contract. CIVIL CODE, art. 491 (Arm.). 
reduction and rescission ${ }^{215}$ and, in B2C cases, additionally replacement); ${ }^{216}$ (3) Cambodia (repair, replacement, price reduction, rescission); ${ }^{217}$ (4) Canada (in many provinces the catalogue includes partial or full price reduction and damages claims for the loss that results from the breach of warranty, and alternatively, repair and replacement in some instances) $)^{218}$ (5) Chile (price reduction and rescission as a general rule, ${ }^{219}$ and in $\mathrm{B} 2 \mathrm{C}$ cases, additionally repair and replacement); ${ }^{220}$ (6) China (repair, replacement, refund of the purchase price); ${ }^{221}$ (7) Hong Kong (partial or full price reduction and damages claims for the loss that results from the breach of warranty); ${ }^{222}$ (8) India (partial or full price reduction and damages claims for the loss that results from the breach of warranty); ${ }^{.23}$ (9) Indonesia (price reduction or rescission); $;^{224}$ (10) Mongolia (repair, replacement, price reduction, rescission), ${ }^{.25}$ (11) Russia (repair, replacement, price reduction, rescission); ${ }^{226}$ (12) South Africa (repair, replacement, refund of the purchase price); ${ }^{227}$ and (13) Switzerland (replacement, price reduction and

215. Lei No. 10.406, de 10 de Janeiro de 2002, Diário Oficial DA União [D.O.U.] de 11.1.2002, art. 441, 442 (Braz.).

216. Lei No. 8.078, de 11 de Setembro de 1990, Código de Protecão e Defesa do CONSUMIDOR (C.D.C.) art. $18 \S 1$ (Braz.).

217. Civil Code, art. 540(1) (2007) (Cambodia).

218. Sale of Goods Act, R.S.B.C. 1996, c 410, sec. 56 (Can.); Ontario Sale of Goods Act, R.S.O. 1990, c S.1, sec. 51 (Can.). The latter choices are, as pointed out by the Office de la Protection du Consommateur, directly available in the province of Quebec, although not explicitly mentioned in the Quebec Consumer Protection Act. Warranties Provided by Law, Office de la Protection du Consommateur (Nov. 24, 2017), www.opc.gouv.qc.ca/ en/consumer/topic/purchase/phone-mail/warranty/legal-warranties/ [https://perma.cc/YU7M -J9RZ].

219. Código Civil [Cod. Civ.] [Civil Code] art. 1857 (Chile).

220. Chilean Consumer Protection Law, art. 20 (Chile).

221. Chinese Contract Law, art. 111 (China).

222. Sale of Goods Ordinance, (2018) Cap. 26, § 55 (H.K.).

223. Sale of Goods Act, No. 3 of 1930, INDIA CODE (1930), sec. 59 (India).

224. Civil Code, art. 1507 (Indon.).

225. Civil Code, art. 254(1)-(2) (Mong.); Law on Consumer Protection, art. 6(3) (Mong.). Note that the possible remedies against the producer of a defective good under the Mongolian Law on Consumer Protection are not specified. Since, however, the producer's liability is not a contractual liability, it must be assumed that the remedies include repair and replacement, but not price reduction and rescission.

226. Grazhdanskil Protessual'nyi Kodeks Rossisskoi Federatskil [GPK RF] [Civil Procedure Code] art. 503 (Russ.) (referring to the sale of defective goods and clarifying that it is the buyer who has the right to choose any of these remedies). Consumer RIGHTS PROTECTION ACT, art. 18 (Arm.) (giving the purchaser, in a similar manner, the explicit right to choose between the remedies in $\mathrm{B} 2 \mathrm{C}$ cases).

227. Consumer Protection Act 68 of 2008 \$56(3) (S. Afr.) (stating that "the supplier must, at the direction of the consumer, either - (a) repair or replace the failed, unsafe or 
rescission). ${ }^{228}$

Occasionally the circumstances determine which remedy is appropriate. An example is provided by Australia, where Australian Consumer Law distinguishes between different levels (of seriousness) of defects. In cases of minor defects, available remedies include repair or replacement as primary remedies and rejection or rescission as secondary remedies. ${ }^{229}$ The seller has, however, the option to discharge his obligation to the buyer by opting for a refund of the purchase price even if the purchaser chooses repair or replacement. $^{230}$ In more serious cases, the purchaser can immediately ask for a price reduction or a refund of the price paid. ${ }^{231}$ A comparable solution is enshrined in the South Korean Civil Code. Its Article 580 allows for damages claims (including immediate price reduction) and rescission. The latter one, however, is limited to more serious cases of defect. $^{232}$

These findings show that significant differences exist in terms of the range of warranty remedies and that a substantial number of jurisdictions provide for a hierarchical structure of remedies. In the context of planned obsolescence, waste reduction, and reaching sustainability goals, however, these differences are of little practical relevance. This is the case because the law in almost all jurisdictions would need to be reformed to prioritize remedies by giving priority to the remedy of repair. It is through the remedy of repair, including the facilitation of self-help repairs, that the sustainability of products can be prolonged. Only when repairs become cost prohibitive or a product is in serial need of repair should replacement be chosen.

defective goods; or (b) refund to the consumer the price paid by the consumer, for the goods").

228. ObligationenRecht, Code des obligations, Codice Delle obligazioni [Code OF OBLIGATIONS] Apr. 1, 2017, art. 206(1) (Switz.), www.admin.ch/opc/en/classifiedcompilation/19110009/201704010000/220.pdf [https://perma.cc/H235-C6HC]. It should be noted that Article 206(2) of the Swiss Code of Obligations gives the seller the option to "discharge his obligation to the buyer by immediately delivering acceptable items of the same kind and making good any loss or damage the buyer has suffered" irrespective of the purchaser's choice of remedy.

229. Id. s. 259(2) (Austl.).

230. Id. s. 261(d)(Austl.).

231. Id. ss. 259(3), 260 (Austl.).

232. Minbeob [Civil Act], Act. No. 471, Feb. 22, 1958, amended by Act. No. 8720, Dec. 21, 2007, art. 571, 580 (S. Kor.). 


\section{Time Factor}

It was previously noted that time periods - warranty duration and prescription periods for bringing claims - are decisive factors or obstacles to the potential of warranty law to solve the problem of planned obsolescence. This is due to the consideration that planned obsolescence defects are by their very nature inherently latent in the sense that they manifest themselves at a much later point than delivery. Jurisdictions might provide for either a more generous, purchaser-friendly period design or aim to limit the potential liability of sellers (and where applicable, third parties, most notably producers) to the greatest justifiable extent. This is largely the result of the need to strike a balance between maximizing the chances to remedy contractual non-conformity on the one hand, and guaranteeing a maximum level of legal certainty on the other, understood as predicting the time-wise exposure of liable parties to possible claims.

An evaluation of the situation in the EU and its Member States illustrated that attempts to harmonize the period framework are an ambitious, yet not necessarily successful, endeavor. The national implementations of Article 5(1) of the CSD on rules on the underlying warranty period (defect manifestation period) and the prescription of possible claims (warranty claim prescription period) showed that some of the Member States made significant use of the legislative leeway granted under the CSD. These findings also showed that jurisdictions have applied a considerable degree of variety when it comes to the time periods.

A considerable number of additionally examined jurisdictions apply a delivery rule, where the commencement of the warranty period (and in the simplest setting, also the prescription period) is linked to the delivery of defective goods. This alone does not mean that the actual chances to utilize warranty law in cases of planned obsolescence are necessarily minimal. Earlier discussed examples that include Ireland and the United Kingdom with relatively long prescription periods (linked to the delivery of the good) showed that comparatively long, delivery-based periods might be of help for purchasers in cases of planned obsolescence. The key focus with respect to the delivery rule is the length of the respective period, rather than the fact that the periods are linked to the point of delivery. Hong Kong, following the United Kingdom, applies a six-year period (calculated from the delivery of the good), ${ }^{233}$ which undeniably is a purchaser-friendly approach. Iceland and Norway, both in principle following the CSD

233. Limitation Ordinance, No. 347, (2011) O.H.K., § 347 (H.K.). 
model, join Hong Kong by taking a nuanced, purchaser-friendly approach. Both countries stick to the delivery rule but extend the relevant warranty period from two to five years with respect to durable goods. ${ }^{234}$

Most delivery rule jurisdictions, however, apply a delivery-based warranty period solution with shorter timeframes (quite similar to the model enshrined in Article 5(1) Sentence 1 of the CSD). Article 493(2) of the Armenian Civil Code, for example, caps the warranty period at two years of delivery (unless the law or the contract itself provides a longer period). ${ }^{235}$ The same is the case under Article 447(2) of the Belarusian Civil Code. ${ }^{236}$ Article 158(2) of the Chinese Contract Law caps the possibility of exercising warranty remedies indirectly by mandating the purchaser to notify the respective seller of a defect within two years of delivery. ${ }^{237}$ With effect of 2013, Switzerland extended the statutory warranty period from one to two years for movables. ${ }^{238}$ Article 210(1) of the Swiss Law of Obligations stresses that this two-year period should also apply in scenarios in which the purchaser cannot detect the defect within that timeframe.

A nuanced, but in essence comparable approach is enshrined in

234. Consumer Sales Act, art. 27(2) (Ice.). See European Comm'N, Consumer Market Study on the Functioning of Legal and Commercial Guarantees for CONSUMERS IN THE EU - COUNTRY Fiche: ICELAND (2015) (providing more detail on Iceland's purchaser-friendly approach); see also Section 27 of the CONSUMER SALES ACT, $\S$ 27 (Nor.), lovdata.no/dokument/NLE/lov/2002-06-21-34 [https://perma.cc/Y3EX-HF7B] (evincing Norway's purchaser-friendly approach). The European Consumer Centres Network (ECC-Net) explains that in the case of hidden defects, the prescription period can actually extend to 13 years in total in the case that the consumer was unaware of the defect; this might point to a partial manifestation rule. ECC-NET, supra note 121, at 102.

235. CIVIL CoDE, art. 332, 337 (Arm.), www.ilo.org/dyn/natlex/docs/ELECTRONIC/836 47/92533/F1027892254/ARM83647.pdf [https://perma.cc/GB7R-KYYE]. The pertinent warranty claim prescription period (for cases in which the defect becomes apparent within two years pursuant to Article 493) follows the general framework of Articles 332 and 337 of the Armenian Civil Code. Possible claims would be barred after three years (calculated from the time the purchaser "knew or should have know[n] of the violation of his right").

236. Civil Code, Law No. 218-Z, 447(2) (1998) (Belr.).

237. General Rules of the Civil Law, art. 158(2) (China). The "claimability" itself, i.e. the right to sue (if notified on time) would follow Article 188 of the Chinese General Rules of the Civil Law, with a prescription period of three years (starting at the time the claimant knows or ought to know about his damage; the absolute period of prescription is twenty years under said provision, starting at "the date of damage"). An English translation is available at www.dimt.it/images/pdf/GeneralRules.pdf [https://perma.cc/6ZAV-P2QC].

238. Obligationenrecht, Code des obligations, Codice delle obligazioni [Code of OBLigations], Apr. 1, 2017, art. 210(1) (Switz.). In the case of immovables, the warranty period is considerably longer. Article 210(1) of the Swiss Law of Obligations caps it at five years (from delivery). 
Articles 471 and 477 of the Russian Civil Code, capping the warranty period at two years from delivery. It should be pointed out, however, that in certain B2C transactions (in cases of more significant defects) consumers may exercise remedies against the producer of the defective good for a considerably longer period of time (which could reach up to ten years). ${ }^{239}$

Some jurisdictions apply the delivery rule with even shorter periods. The remedies provided against the seller under Article 21 of the Chilean Consumer Protection Act, for example, are available for only three months from delivery. The alternative regime of the Chilean Civil Code might not be of great significance either, capping the availability of remedies at six months for movables and one year for immovables from delivery. ${ }^{240}$ A sixmonth solution (commencing from delivery) can furthermore be found in the Philippines, where Article 1571 of the Filipino Civil Code enshrines such a period for cases of implied warranties, ${ }^{241}$ as well as in Kosovo, ${ }^{242}$ Mongolia, ${ }^{243}$ and South Africa. ${ }^{244}$

Vietnam joins the group of jurisdictions that adopted a delivery rule, but at the same time provides for a remarkably unique solution. Pursuant to Article 446 of the Vietnamese Civil Code, purchasers of defective goods have the right to exercise remedies if the defect becomes apparent within the warranty period. ${ }^{245}$ The law, however, fails to specify the length of this warranty period. The term "warranty period" can furthermore be found in Article 21 of the Vietnamese Law on the Protection of Consumer Rights

239. Consumer Protection Act, art. 19(6) (Russ.).

240. Código Civil [Cod. Civ.] [Civil Code] art. 1866 (Chile).

241. Longer periods might apply in cases of express warranties, particularly in the oneyear period pursuant to the CONSUMER ACT, art. 68(e) (Phil).

242. CIVIL CODE, art. 465(2) (Kos.) (obliging the purchaser, for non-B2C cases only, to notify the seller within eight days of detecting the defect).

243. CIVIL CODE, art. 254(6) (Mong.) (referring the warranty period); LAW ON CONSUMER PRoteCtion, art. 5(3) (making an additional reference to the warranty period). The warranty claim prescription period follows the general prescription scheme of Article 75 of the Mongolian Civil Code (according to the information provided by Navchaa Tseveen on Dec. 14, 2018) (information on file with authors).

244. Consumer Protection Act 68 of $2008 \S 55(2)(c)$ (S. Afr.). This short period is remarkable because Section 55(2)(c) of the Act lists durability explicitly as one factor to determine the contractual (non)conformity of a product.

245. Civil Code No. 91/2015/QH13 (Nov. 24, 2015) art. 446 (Viet.), www.wipo.int/wip olex/en/text.jsp?file_id=445413 [https://perma.cc/RU9W-4UQN]. It should be noted that the Vietnamese Civil Code states: "(1) If agreed by parties or provided by law, a seller has the obligation to provide a warranty for the object for sale and purchase for a certain period, hereinafter referred to as the warranty period. (2) The warranty period shall be calculated from the time when the purchaser has the obligation to accept the object." 
but is (again) left unspecified. In practice, one can find different lengths of warranty periods granted by sellers at will. ${ }^{246}$ Statutory specifications might be preferable, particularly for those scenarios in which the contractual parties do not explicitly agree on the length of the warranty period. ${ }^{247}$

Other jurisdictions follow the previously discussed objective manifestation rule ("detectability rule"). In these cases, the relevant period would not commence at the delivery of the product, but at the point in time in which the purchaser detected or should have detected the defect. One example is Article 547(1) in combination with (2a) of the Cambodian Civil Code. Pursuant to the latter, the starting point of the one-year period within which the seller would have to exercise a listed warranty remedy is "the date that the buyer knew or should have known of the existence of the nonconformance or damage. $" 248$

Another, more refined example is Australia. Sections 262 and 273 of the Australian Consumer Law differentiate between claims against sellers (Section 262) and damages claims against producers (Section 273) for defective goods. Both, to a certain extent, apply an objective manifestation rule but provide for different solutions. ${ }^{249}$ Section 273 (with respect to producers) links the commencement of the three-year damages claim to the point of detectability. Section 262, on the other hand, gives the purchaser the right to exercise his (basic) warranty remedies against the seller during a rejection period that takes account of objective circumstances, ending at the reasonable point at which one could expect the defect to become apparent. To determine this point, Section 262(2) includes the following parameters:

(a) the type of goods; and

(b) the use to which a consumer is likely to put them; and

246. Civil CODE, art. 547(1) (2003) (Cambodia), www.trc.gov.kh/wpcontent/uploads/2015/05/civil-code-en.pdf [https://perma.cc/GVR9-JT25]. See, e.g., Standard Warranty Period, HÄFELE, www.hafele.com.vn/en/info/service/customer-care/stan dard-warranty-period/43255/ [https://perma.cc/MJ4Y-YDYP] (last visited May 9, 2019) (listing various standard warranty periods). In a similar vein is the information provided by Phong Pham on Dec. 8, 2018 (on file with authors).

247. Residential Housing Law No. 65/2014/QH13 (Dec. 29, 2014) (Viet.). Sectoral, statutory warranty periods are scarce. One notable exception applies to immovables, where Article 85(2) of the Vietnamese Residential Housing Law specifies warranty periods (that reach from 24 to 60 months as from the completion of the building depending on the type of housing) (information provided by Phong Pham on Dec. 12, 2018; on file with authors).

248. Civil CODE, art. 547(2a) (2003) (Cambodia), www.trc.gov.kh/wp-content/uploads/2 015/05/civil-code-en.pdf [https://perma.cc/GVR9-JT25].

249. Australian Consumer Law 2010 (Cth) ss 262, 273 (Austl.). 
(c) the length of time for which it is reasonable for them to be used; and

(d) the amount of use to which it is reasonable for them to be put before such a failure becomes apparent. ${ }^{250}$

Delivery-detached periods are of further relevance in the examined Canadian provinces of British Columbia, Ontario and Quebec. Defect detectability is the anchor point in British Columbia and Ontario, ${ }^{251}$ while actual detection is the decisive factor for determining the commencement of the relevant warranty claim prescription period in Quebec. ${ }^{252}$

Reasonableness is of comparable relevance in India. In the absence of a clear, statutory warranty period, courts tend to take a case-by-case approach to implied warranty scenarios. Depending on the circumstances, courts apply different timeframes that can be considerably longer than most of the delivery-rule solutions that were outlined above. ${ }^{253}$ Indonesia does not provide for a clear warranty period. Instead, Article 1511 of the Indonesian Civil Code states that the purchaser must exercise his rights "as soon as possible," 254 taking account (inter alia) of the "nature of the defect." 255

As was the case already with EU Member States, a look at additional jurisdictions shows that some countries take a more generous approach by adopting a subjective manifestation rule. Under this scheme, the decisive point is the moment in which the purchaser actually detects the defect (and not the objective detectability). Article 582 of the South Korean Civil Code, for example, links the commencement of the warranty period neither to the delivery of the good nor to the detectability of the defect, but to purely subjective parameters. It stipulates that possible remedies "shall be exercised by the buyer within six months from the time when he was first aware of" the defect. ${ }^{256}$ In a similar, yet even more generous vein, Article

250. Australian Consumer Law 2010 (Cth) s 262(2) (Austl.).

251. Limitations Act, S.O. 2002, c 24, sched. B, secs. 4, 5 (Can.); Limitations Act, S.B.C. 2012, c 13 (Can.).

252. Civil Code of Québec, S.Q. 2012, art. 2925 (Can.); see Prescription: Legal Deadlines, EduCALOI, www.educaloi.qc.ca/en/capsules/prescription-legal-deadlines [https:// perma.cc/F8UA-LLHD] (describing the basics of "prescription").

253. Information provided by Pankaj Singla on Dec. 2, 2018, with reference to case law that includes Maruti Udyog v. Om Sahai Bhatnagar (more than eight years from delivery) and Honda Siel Cars India Ltd v. Rohit Jain (more than five years from delivery).

254. Civil CoDE, Art. 1511 (1847) (Indon.), www.refworld.org/pdfid/3ffbd0804.pdf [htt ps://perma.cc/P22X-XR55].

255. Id.

256. Minbeob [Civil Act], Act. No. 471, Feb. 22, 1958, amended by Act. No. 8720, Dec. 21, 2007, Art. 582 (S. Kor.), www.moleg.go.kr/english/korLawEng?pstSeq=52674 [https://p 
566 of the Japanese Civil Code (which takes effect in April 2020) provides that the purchaser has to notify the seller about the defect within one year of the discovery of the defect by the purchaser. ${ }^{257}$

The Ukrainian Civil Code applies a mix of the (objective) delivery rule and the subjective manifestation rule and allows for an interesting exception for latent defects. Article 680(2) of the Ukrainian Civil Code links, in principle, the commencement of its two-year warranty period (three years in the case of immovables) to the delivery of the defective good. ${ }^{258}$ One might understand the period stipulated by Article 680(2) as paralleling the "defect manifestation period" ("warranty period" in a narrow sense) of Article 5(1), Sentence 1 of the CSD. Article 681 of the Ukrainian Civil Code introduces a second period of one year within which the purchaser may file a claim. This provision corresponds to the "warranty claim prescription period" of Article 5(1), Sentence 2 of the CSD. Two points have to be emphasized. First, unlike the case under the $\mathrm{CSD}$, the one-year Ukrainian warranty claim prescription period (Article 681) might lapse before the end of the warranty period under Article 680(2) of the Ukrainian Civil Code. This is due to the shorter length of the warranty claim prescription period. Second, Article 680(5) of the Ukrainian Civil Code introduces a special consequence for truly latent defects. It reads as follows: "If the buyer detects the defects after expiration of the warranty period... the seller shall bear responsibility, provided the buyer proves that the goods' defects appeared prior to the goods transfer or by the reasons exist[ing] before this moment" (emphasis added). ${ }^{259}$ This allows for filing claims (within the one-year subjective manifestation period of Article 681), even if defects become apparent after two years of delivery.

Another interesting mix of different schemes can be found in Brazil. The general framework of the Brazilian Civil Code proceeds from a restrictive delivery rule of thirty days for movables and one year for immovables. ${ }^{260}$ With respect to movables, the (objective) warranty period could, however, expand to 180 days if the defect is inherently latent. ${ }^{261}$ In

erma.cc/UA9L-QSEV].

257. The prescription period itself follows the general rule of (the revised) Article 166 of the Japanese Civil Code (five years from detectability, ten years absolute). Article 566 of the Japanese Civil Code (in its old version) introduced a one-year prescription period that commenced at the point the purchaser actually noticed the defect.

258. Civil Code [C. CIV.], art. 680(2) (2017) (Ukr.).

259. Id. art. 685 (2017) (Ukr.).

260. Código Civil [C.C.] art. 445 (Braz.).

261. Id. at $\S 1$ (Braz.). 
this case, the absolute limit of 180 days is combined with a subjective manifestation rule of thirty days, which commences at the time the purchaser becomes aware of the defect. ${ }^{262}$ In B2C cases, a more generous framework (enshrined in the Brazilian Consumer Defense Code) would apply. The starting point is again the delivery of the defective good, with a warranty period of thirty days for non-durable goods and ninety days for durable goods. ${ }^{263}$ For inherently latent defects, the law (again) switches to a subjective manifestation rule and stipulates that the said rules should commence at the point in time in which the purchaser notices the defect. ${ }^{264}$ Unlike the warranty law model of the Brazilian Civil Code, however, the Brazilian Consumer Defense Code does not provide for a specific absolute warranty law period.

This excursion into period designs proves that different jurisdictions apply significantly different models and solutions. From a planned obsolescence perspective, noteworthy is the fact that most schemes seem to be unsuitable to answer the phenomenon comprehensively. In particular, in scenarios in which the defect becomes apparent considerably late, the chances of claiming non-fault-based warranty remedies become minimal.

\section{Fixing the Problem of PlanNed Obsolescence: Possible WAYS FORWARD FROM A WARRANTY LAW PERSPECTIVE}

The above analysis of warranty law and its potential application to the problem of product durability or planned obsolescence shows a path forward for the law to better address this growing problem. This Part gleans from the previous parts, a number of law reform recommendations that provide means to address the problem of product durability through changes in warranty law. The recommendations include: (1) extending statutes of limitations, tolling, and statutes of repose periods to accommodate delayed cases of planned obsolescence; (2) addressing the issue of constituting an inherently latent defect under warranty law by introducing tailor-made period designs; (3) re-examining the state-of-theart defense; (4) mandating disclosure requirements; (5) enacting an implied warranty of durability; (6) prioritizing the remedy of repair over that of replacement; and (7) recognizing a consumer's right to repair.

262. Id.

263. Código de Proteção e Defesa do Consumidor [C.D.C.] art. 26 (Braz.).

264. Id. at $\S 3$ (Braz.). 


\section{A. Extending Mandatory Product Warranty Periods}

The problem presented by planned obsolescence is that the shortened lifespan of the product often appears after the running of the statute of limitations. This is because planned obsolescence is mostly latent in nature. It also because the statute of limitations can be relatively short in length. ${ }^{265}$ Uncertainty is amplified because limitation periods vary across countries and across American states. Further, the suspension of the running of limitation periods (tolling) also varies across jurisdictions, as do other limitation periods, such as the statute of repose or laches.

\section{Tolling}

Given that evidence of planned obsolescence may not become apparent until years after the expiration date of an express warranty or an extended warranty or service contract, the statute of limitations should be suspended or tolled until the planned obsolescence is discovered or should have been discovered. ${ }^{266}$ As discussed below, one avenue to address this problem is for the courts to recognize planned obsolescence as an inherent defect, thereby tolling the limitation period under products liability law. However, any ambiguity regarding the timeliness of a claim would be better clarified with an extended, implied, mandatory warranty period under an implied warranty of durability, also discussed below, with specified tolling provisions.

\section{Statutes of Repose}

Laches or statutes of repose act to terminate an unexpired statute of limitations period that has been tolled beyond a reasonable or fixed period of time. ${ }^{267}$ The rationale for the statute of repose is to remove the

265. The law of Pennsylvania limitation periods provides for two years for injury to persons or property related to defects of products. 42 PA. CONS. STAT. $§ 5524$ (2004).

266. Common-law tolling refers to the suspension or stopping of the statute of limitations from running due to recognized events. The U.S. Supreme Court offered a test for tolling - the claimant had been actively pursuing its rights (such as through settlement negotiations, mediation or arbitration). See Pace v. DiGuglielmo, 544 U.S. 408, 418 (2005) (stating that the requirements for equitable tolling are a diligent pursuit of rights and some extraordinary circumstances that acted as a barrier).

267. Laches was a doctrine found in equity and later became a part of the common law. The doctrine allowed courts the discretion to dismiss claim that they deemed to be brought after an unreasonable delay. See Laches Law and Legal Definition, USLEGAL, https://definit 
uncertainty to a producer or contractor of a long and uncertain length of time for filing liability claims. They are generally enacted to protect certain items with unusually long lifespans, such as airplanes and real estate construction contracts. For example, Pennsylvania law provides a twelve-year period to bring claims for "[a]ny deficiency in the design, planning, supervision or observation of construction or construction of the improvement." ${ }^{268}$ Needless to say, these statutes would need to be reassessed to determine if they need to be extended in cases of planned obsolescence.

\section{B. Recognizing Planned Obsolescence as a Latent Defect}

This section suggests that cases of planned obsolescence are akin to latent defects recognized in tort law and, therefore, the limitation period for planned obsolescence should begin when the obsolescence is discovered (or at least objectively discoverable). If this is done, then a manufacturerseller's defenses of state of the art and disclosure of durability should be allowed.

\section{Limitation Period Begins at Time Buyer Knew (or Should Have Known) of Defect}

Planned obsolescence warranty-relevant defects are constituted if products fail to perform for the reasonably expected lifetime of a product. In this context, planned obsolescence should be recognized as a latent defect in the sense that it is not visible at the time of delivery, but manifests itself later, in many cases significantly later. The above study showed that

ions.uslegal.com/l/laches [https://perma.cc/GXS5-KFGN] ("Laches is an equitable form of estoppel based on delay. The theory behind allowing the defense is that the law shouldn't aid those who "sleep on their rights."'). Statutes of repose serve the same purpose but are legislative enactments that set fixed periods of time for bringing an action.

268. 42 PA. Cons. Stat. $§ 5536$ (1978). This limitation period has been broadly construed to include the installation of an industrial freezer at a manufacturing plant. See DeSantis v. Frick Co., 745 A.2d 624, 625 (Pa. Super. Ct. 1999) (agreeing with the lower court's ruling that the statute of repose barred any wrongful death claim against the manufacturer of a freezer that malfunctioned approximately 30 years after installation). However, the statute of repose does not protect suppliers of materials that become component parts of a construction project. See McConnaughey v. Bldg. Components, Inc., 637 A.2d 1331, 1334 ( $\mathrm{Pa}$. 1994) (holding that the statute of repose does not protect the manufacturer of components used in construction); see also Ferricks v. Ryan Homes, Inc., 578 A.2d 441, 445 (Pa. Super. Ct. 1991) (holding that a plywood manufacturer was not entitled to protection under the statute of repose). 
a considerable number of jurisdictions apply warranty schemes that are unsuitable for helping in cases in which the reasonably expected lifetime exceeds two years. This is mostly the result of the widespread use of twoyear warranty periods that run from the delivery of the defective product. These inflexible prescription or limitation periods compound the difficulties of bringing an action for planned obsolescence. Classifying the defect as a failure to meet the respective durability standards does not help in these cases. Currently, warranty law would not capture durability noncompliance since the planned obsolescence would not become apparent within the relevant warranty period or because of a lapse of time for filing a complaint.

The survey of available limitation period designs highlighted some notable attempts to strike a balance between the desire to limit possible claims and allow for actions based on fairness rationales in cases where products do not meet durability standards. Three distinct strategies are evidenced by the survey of comparative warranty law. Extending the warranty periods beyond two years of delivery (without changing the delivery rule model) can be considered as the least radical approach from a seller's perspective because it aims to guarantee a high level of overall legal certainty. Sellers would easily be able to predict the end of the respective warranty periods. The limitation period would simply start at the point of delivery. The longer the warranty period the more cases of planned obsolescence will be covered. Existing examples of this "extended statutory warranty period" approach are found mainly in Europe. Hong Kong is the only non-European example of the implementation of extended limitation periods. The disadvantage of this solution is that it fails to provide for comprehensive consumer or purchaser protection against planned obsolescence. Delivery-based period designs tend to ignore the question of durability.

Taking account of expected product lifetimes can more appropriately be realized with the help of two alternative solutions, which apply more flexible schemes. The more balanced approach links the commencement of the relevant limitation period to the detectability of the defect and not the time of delivery. This strategy was previously labeled as the objective manifestation rule, which has already been utilized in a number of countries. In our study, roughly one sixth of the examined jurisdictionsof which more than half are non-European-make use of such a commencement rule. From a balance of interest perspective, arguably the biggest advantage of this solution is that it emphasizes the durability aspect by applying an objective standard linked to the point of detectability. A verification or proof of the potential of this approach can be seen in the 
decision to integrate it into the Common European Sales Law (CESL), which was proposed in the form of an EU regulation in 2011. ${ }^{269}$ Article 179(2) and Article 180(1) of the CESL enshrined a general two-year period - also applicable in warranty law cases - that commences at the point of detectability. ${ }^{270}$ Despite strong support by the European Commission, the CESL was not been enacted into law. Nevertheless, the significant support from legal academia shows that the objective manifestation rule is a promising compromise to safeguard purchasers' interests in the durability of products.

A third approach is represented by the subjective manifestation rule, which fixes the commencement period of warranty claims at the point of the actual discovery of the defect by the purchaser. This is the most propurchaser approach because it prioritizes the individual capability to detect relevant durability defects. Under this rule, sellers are exposed to a considerable degree of unpredictability. Depending on the purchaser, the actual point of discovery could substantially differ from case to case. A minority of jurisdictions examined in the survey has adopted this rule.

\section{State of the Art: Existence Versus as Practiced}

Tort or products liability law recognizes the state-of-the-art defense. There are two variations of the state-of-the-art defense: one asserting that the manufacturer followed "industry-wide standards to which the [manufacturer] ha[d] conformed" and the other arguing that the manufacturer could not have produced a safer product "within the current limits of scientific knowledge." ${ }^{271}$ The start-of-the-art defense is most useful in the case of design defects. Planned obsolescence is often an outcome of a poor design, as well as the use of poor manufacturing materials or component parts.

The state-of-the-art defense should be modified in cases of planned obsolescence. First, industry standards may allow for planned obsolescence since the same incentive structures (creating a market for repair parts and increasing future sales of products to replace obsolescent products) often persist throughout the major manufacturers in a given industry. Second, the use of the current limits of scientific knowledge

269. Proposal for a Regulation of the European Parliament and of the Council on a Common European Sales Law, COM (2011) 635 final (Oct. 10, 2011).

270. Id. at art. 179(2), 180(1).

271. James T. Murray, Jr., The State of the Art of Defense in Strict Products Liability, 57 MARQuetTE L. REV. 649, 651-52 (1974). 
standard is a better fit for safety defects and not issues of durability. A more appropriate affirmative defense would require the manufacturer to show that it used an appropriate design and materials that would ensure a durable product (expected lifespan of a reasonable consumer). Cost constraints are often prohibitive in obtaining optimal durability. Thus, the standard is not absolute durability but reasonable durability. The expectation of durability may be adjusted through adequate disclosure, which is discussed in the next section.

\section{Defense: Disclosure of Durability}

Disclosing information regarding the durability of products can be considered as part of the solution. The idea of durability diverges between manufacturers and buyers mostly due to informational asymmetry. The manufacturer retains inside information on the durability of a product as engineered and produced. The buyer, working without such information, often expects that the product will function beyond the period of the manufacturer's planned obsolescence. In order to encourage manufacturers to disclose information on products' likely lifespans, a disclosure of durability defense should be recognized. Providing buyers with information on expected product lifetimes increases transparency and facilitates informed decision-making. The informational benefit of disclosing expected durability levels has been experienced in some countries that have already explored lifespan labeling.

A 2016 EU study on the impact of lifespan labeling concluded that labeling would have a positive double-effect. The study argued that the question of durability is of increasing importance in consumers' decisionmaking process. ${ }^{272}$ Expanding the use of lifespan labels would satisfy consumers' wishes for increased transparency. As a result of this transparency, and knowing that consumers tend to purchase longer-lasting products, manufacturers would be incentivized to pursue more sustainable production methods and produce more environmentally-friendly products, which are linked to increased durability. The EU study came to the conclusion that "[o]n average, sales of products with a label showing a longer lifespan than competing products increased by $13.8 \% .273 \mathrm{~A}$ considerable number of countries, mostly from Europe, are in the process

272. European Econ. \& Soc. Comm., The Influence of Lifespan Labelling on Consumers: ExeCutive Summary 2 (2016).

273. Id. 
of exploring the potential of lifespan labeling. Countries such as Austria, ${ }^{274}$ Belgium $^{275}$ and France ${ }^{276}$ are leading the discussion over the need for durability labeling. Such labeling would serve consumer interests and the need for sustainable production and consumption in order to protect the environment. From a policy-debate perspective, arguably the most contested question is how to integrate lifespan labeling into possible remedial schemes. This issue will be discussed at the end of this Part.

\section{Issues Relating to EWSCs}

Further evidence of planned obsolescence is seen in the creation of the multi-billion dollar extended warranty service contract industry (EWSC) with an annual growth rate of $7.33 \%{ }^{277}$ Sellers of extended warranties, who are often the manufacturers of products, rely on internal information of durability when setting the EWSC period. The sale of EWSCs generates independent revenue sources for manufacturers, retailers, and third-party insurers. The allocation of the price of the premium for the EWSC for repair expenses is about twenty percent, with the rest taken in different forms of profits. ${ }^{278}$

The issue in the EWSC industry is not the long-term durability of the product, but the durability of the product during the period of the EWSC:

274. The Austrian Standards Institute, for example, designed a (non-binding) "Label of Excellence" for durable, repair-friendly designed electrical and electronic appliances. It differentiates between two basic categories: home entertainment equipment ("brown goods" with a recommended durability of minimum five years) and household appliances ("white goods" with a recommended durability of minimum ten years). AUSTRIAN STANDARDS INST., supra note 24.

275. See, e.g., SÉNAT De Belgique, supra note 25 (proposing a resolution to combat the planned obsolescence of energy-related products).

276. See, e.g., Marion Candau, France Pushes for Product 'lifetime' Labelling, EURACTIV (Feb. 15, 2018), www.euractiv.com/section/circular-economy/news/france-pus hes-for-product-lifetime-labelling [https://perma.cc/66R6-49GY] (describing the French government's plan to implement a product life label and advocating for similar action at the EU level).

277. Mid-Year Service Contract Report, WARRANTY WeEK 1 (Oct. 9, 2014), https://ww w.warrantyweek.com/archive/ww20141009.html [https://perma.cc/9YUL-QZGP] (stating that consumers will pay nearly $\$ 40$ billion a year for product protection plans); YADAV, supra note 43 (stating that the extended warranty industry has grown by approximately $7.33 \%$ annually for the past six years).

278. A recent survey showed the allocation of payment for EWSC as follows: $19.8 \%$ for payment of claims, $4.95 \%$ in a reserve fund, and the rest for profits and fees; the reserve fund, if not used, would result in additional profits. The SAFE Guys, WARRANTY WEEK (Sept. 28, 2004), https://www.warrantyweek.com/archive/ww20040928.html [https://perma. cc/37LA-MPGR] (last accessed Jan. 25, 2019). 
The certainty of generating great profits is due to the planned or engineered obsolescence of a product extending beyond the term of the EWSC. Putting it in more sinister terms, the manufacturer plans and produces its products to fail, in order to generate future revenues related to the products' lack of durability, but beyond the time of the EWSC. ${ }^{279}$

An effective strategy to curtail planned obsolescence of products through reform of warranty law should also look at the need to cover the largely unregulated EWSC industry.

\section{Implied Warranty of Durability}

Previously, it was argued that planned obsolescence can be regarded as part of warranty law. Usually, parties do not explicitly integrate the expected lifetime in the contract. But the durability notion is widely considered to be an expression of implied quality standards that exist at least in B2C situations. Some examined jurisdictions-Armenia, Australia, the Canadian provinces of British Columbia and Quebec, Hong Kong, Mongolia and South Africa-go one step further and explicitly list statutory durability parameters as quality criteria relevant to warranty law. The laws correctly classify durability as within the scope of warranty law by applying reasonable expected lifetime standards. The durability standards are recognized based on product-group durability benchmarks that indicate reasonably expected product-group lifetimes. If not within an acceptable range of tolerance from such standards, durability shortfalls may result in a claim of breach of warranty.

Identifying product group benchmarks and defining acceptable ranges of deviation is admittedly a difficult task. But the Finnish example shows that it is possible. As discussed earlier, the Finnish Consumer Disputes Board has the competence to issue lifespan standard ranges for different product categories. If a product falls significantly short of the applicable target, a warranty-relevant defect is assumed. The advantage of such an approach can be seen in its objectivity and comprehensiveness. Standard ranges set minimum durability limits. At the same time, however, they allow producers to design their products quite autonomously in the sense that falling short of the average durability of comparable products does not necessarily constitute a warranty defect. Defects are assumed only if the durability deviation is considered substantial and unacceptable.

279. DiMatteo \& Wrbka, supra note 45 , at 524. 
To accommodate these considerations, the above-summarized objective-manifestation-period scheme can be seen as the most suitable period design. The use of lifespan standard ranges and lifespan labeling offers an objective parameter to determine the point of defect detectability. Thus, products that survive their stipulated lifespans would not constitute a basis for an actionable warranty claim as, for example, the Finnish model shows.

Alternatively, strict products liability law in the U.S. is not a good fit for protecting consumers from planned obsolescence. This is because strict products liability law requires that the product must be shown to have a defect that makes the product unreasonably dangerous when used in the intended way. Most cases of planned obsolescence relate to the functionality or durability of the product, which normally does not make the product unreasonably dangerous. Thus, any such durability protection would have to be found in a claim of breach of express warranty ${ }^{280}$ or the implied warranty of merchantability. ${ }^{281}$ Breach of express warranty claims may expire after a short period of time, such as one year. Manufacturers may disclaim the implied warranty of merchantability, which is common practice. ${ }^{282}$ In order to protect consumers from planned obsolescence, American warranty law would have to be substantially revised. The better solution would be to recognize a non-disclaimable implied warranty of durability with an extended limitation period, as discussed previously.

\section{E. Remedies: Duty to Repair}

This section argues for the prioritizing of the remedy of repair over that of replacement. In order to prevent waste, the manufacturer-seller should be required to make a prompt repair of faulty products. Only after a good faith effort to make repair should replacement be used as a remedy. The section also argues for the recognition of a consumer's right to selfrepair.

\section{Prioritizing Repair over Replacement}

Most countries provide a menu of remedies or cascade remedial schemes. Repair and replacement enjoy priority over secondary remedies, such as price reduction and rescission. From an environmental perspective,

280. U.C.C. § 2-313 (AM. LAW InST. \& UNIF. LAW COMM’N 2012).

281. U.C.C. § 2-314 (AM. LAW Inst. \& UNIF. LAW CoMm’N 2012).

282. U.C.C. § 2-315 (AM. LAW Inst. \& UNIF. LAW Comm’N 2012). 
the consequences of repair and replacement differ widely. The negative impacts of replacement on the environment outweigh those of repair. This is due to the fact that replacement creates considerably more waste than does repair. Considering the differentiation in environmental or sustainability costs between repair and replacement, remedial schemes found in the United States and other countries should be reformed to prioritize repair over the replacement remedy.

The law at the pan-EU level (Article 3(3) of the CSD), Member State legislation implementing the CSD, and non-EU jurisdictions that follow the CSD give the choice to the buyer to receive repair or replacement. It can be argued that this is an improvement because consumer choice overcomes the bargaining power disparities that previously allocated the choice to the seller. Under the American scheme, the choice to repair or replace lies with the seller.

From an environmental perspective, either solution (leaving the choice to the buyer or the seller) is not the best possible solution. Environmentally friendly purchasers and sellers would be inclined to choose a resourceefficient way of bringing the defective good into contractual conformity by opting for repair instead of replacement. However, less environmentally friendly purchasers are likely to choose a new replacement despite a product being repairable. A better or more sustainable model would be to take the choice away from either party by obligating the seller to promptly repair. The content of such a model would include the use of replacement when repair is cost-prohibitive, provide for replacement after a maximum number of repairs have been reached, and give a purchaser the right to a temporary substitute product in cases of unduly long periods of repair.

In sum, even if it may be easier to replace a product, repair should be made the preferred remedy unless repair proves to be otherwise unreasonable. ${ }^{283}$ Additionally, the law, especially where the product has been heavily used, could allow the seller to replace with refurbished goods. This would not necessarily be as waste-preventing as repair, but it would increase the incentive to recycle obsolete products.

283. Sustainability goals also require in cases of replacement that the manufacturer be obligated to mine the goods being replaced for reusable materials. The idea of recognizing post-replacement obligations of a manufacturer has been suggested previously: "Extended Producer Responsibility (EPR) is a policy that shifts responsibility for collection and recycling of post-consumer goods from governments to producers." Conrad B. MacKerron, Moving Toward Sustainable Consumption in Electronics Design, Production, and Recycling, 31 Utah ENVTL. L. ReV. 117, 117 (2011). 


\section{Right to Self-Repair}

There are two distinct movements whose goals are to provide consumers a right to repair. One is embedded in consumer protection rationales. Consumers should be allowed to repair their own products rather than be forced to seek more expensive alternatives (higher costs of repair in manufacturer-certified repair shops or to purchase a new product). The parallel movement relates to sustainability goals of governments and international instruments aimed at reducing waste and pollution in response to climate change.

In the area of consumer protection, there is now a model law recognizing a consumer's right to self-repair and the reciprocal duties of manufacturers. ${ }^{284}$ The four parts of the model law include:

(1) mandating disclosure of information that will allow repairs;

(2) mandating the availability of parts and tools to facilitate repairs;

(3) mandating disclosure of information to allow security protections to be reset; and

(4) forbidding any contracting-around of such provisions in [contract] terms between authorized repair providers and the original equipment manufacturers. ${ }^{285}$

Examples of designs that make self-repair difficult include affixed or glued batteries in electronic products and the Apple screw that prevents opening and repairing of Apple products with ordinary types of screwdrivers. In order to make self-repair possible, companies should be required to make available the manuals needed to effectuate self-repair, along with maintaining an inventory of repair parts.

The sustainability movement encourages consumers to seek out goods that were produced using environmentally friendly processes and that advance the goals of sustainability. For example, the EU Ecolabel criteria take a lifecycle approach that assesses the production cycle from the extraction and use of natural resources, the production process, the end of the product's lifecycle, the use of recycling of reusable materials, and methods to use any waste in a productive way. ${ }^{286}$ Ultimately, sustainability

284. Repair.org, Model State Right-to-RePair LaW (2018), https://repair.org/s/Righ t-to-repair-Model-state-law-7-24-18.docx [https://perma.cc/Z3WQ-XLX5].

285. Leah Chan Grinvald \& Ofer Tur-Sinai, Intellectual Property Law and the Right to Repair, 88 FORDHAM L. REV. (forthcoming 2019) (manuscript at 15), http://ssrn.com/abstrac $\mathrm{t}=3317623$ [https://perma.cc/3N3T-A4TD].

286. See European COMmission, EU ECOLABEl FOR CONSUMERS 1 (2019), http://ec.euro 
depends on the efficient use and re-use of sources and materials. In addition, longer-lasting products reduce the need for natural resources and decrease waste. From a consumer perspective, many products do not last as long as a purchaser may have reasonably expected. In recent years, environmental concerns linked to sustainable production and use of goods have intensified the planned obsolescence debate. Increasing the durability or functionality of products has become a core sustainability goal.

From the perspective of warranty law, the right to self-repair is relevant. The key point of intersection or conflict relates to classifying the lifetime-ending irreparability of a product as a planned obsolescence defect. As discussed earlier, planned obsolescence refers to cases in which the usability of a product is prematurely ended (as the result of a manufacturer's strategy). The question arises whether cases of irreparability fall under this definition. A parallel can be drawn from defining planned obsolescence as a latent defect. The latent defect is described as a product's failure to perform for a reasonably expected lifetime. Irreparability can be classified as planned obsolescence if it is, at least partially, the reason why a product did not meet expected lifetime standards. However, irreparability itself cannot be regarded as relevant to warranty law. Under warranty law, a product's failure to meet its expected product lifetime relates to the end of usability regardless of whether the defective product can be repaired or not. Hence, irreparability can be evidence of planned obsolescence, but in itself would not be a violation of current warranty law.

The question of whether or not products are repairable could be treated autonomously in a warranty-law context. This is particularly the case if it can reasonably be expected that a product is repairable. This is a separate issue than that of planned obsolescence. In this scenario, it is not so much a question of defect due to durability as it is a question of irreparability of the product. However, the simplest way to recognize the right to self-repair is to incorporate it into warranty law. In sum, warranty law would need to be expanded to include protection against actual defects and a separate duty of reparability.

pa.eu/environment/ecolabel/documents/label_you_can_trust.pdf [https://perma.cc/4878-C6 U9] (describing the EU Ecolabel designation). 


\section{CONCLUSION}

This article explores whether the claim of breach of warranty can be utilized to deal with the problem of planned obsolescence through a review of warranty laws in more than fifty countries worldwide. This article concludes that under certain circumstances warranty law can be useful in regulating cases of planned obsolescence. The analysis asserts that products with unduly short lifespans should be considered as warranty-lawrelevant defects. In the majority of cases, this would be achieved by applying an evaluating parameter of reasonable expectations. Some jurisdictions go further and enshrine durability and reasonable product lifetimes explicitly into their warranty law schemes. We can also see examples where selected authorities have the ability to issue lifespanstandard ranges for different product categories that can help identify possible durability-related, warranty-relevant defects.

The review of warranty law presented in this article reveals one major concern. In the vast majority of cases, warranty schemes are subject to specific, comparatively short or inflexible limitation periods. This issue comes in two forms: short warranty periods covering liability for defects and short prescription periods for filing warranty claims. Short time periods are made shorter when the law commences the period from the time of the delivery of the product. In many cases, these periods would arguably be too short to cover planned-obsolescence-related, latent defects. The article reveals noteworthy exceptions to this rule. Possible solutions to the problem of planned obsolescence can be found in jurisdictions that either provide more generous time periods or apply nuanced approaches that take account of the hiddenness of defects. These jurisdictions apply either a subjective or objective manifestation rule - depending on whether the commencement of a period is linked to the actual knowledge of the defect or its detectability. Regardless of the approach taken, jurisdictions that provide timeframes to effectively respond to the problem of planned obsolescence remain scarce.

This article concludes that current warranty law is not suited to address or regulate products that are designed to prematurely fail. One problem is that applicable implied warranties are easily disclaimable. The European Consumer Sales Directive (CSD) provides additional consumer rights but fails to decisively deal with the issue of timely claims. Article 5 of the CSD and Article 10 of the new CSD merely introduce minimum standards (two years from delivery). From a planned obsolescence perspective, this will often prove to be too short of a time period. Purchaser-friendly jurisdictions have responded with more generous 
schemes through longer warranty periods and more flexible prescription periods that are designed to link the detectability of a defect to the commencement of the limitation period. Likewise, Article 180 of the Proposal for a Regulation on a Common European Sales Law (CESL) adopted the objective manifestation rule, which commences the warranty period from the point of detectability. Unfortunately, the warranty solution proposed with the CESL was not enacted into law. The findings of our study indicate that, unlike other warranty-relevant issues such as the definition of warranty-law-relevant defects or the catalogue of available remedies, time-related aspects are much more difficult to harmonize. Nonetheless, the problem of planned obsolescence persists beyond the current periods of warranty protection in most jurisdictions. The article proposes a number of changes in national warranty laws, such as prolonged or flexible period designs and the creation of an extended warranty of durability in order to directly confront the problem of planned obsolescence.

From a cross-border trade perspective, the existing differences in warranty law create uncertainty for all parties involved. Sellers could be exposed to significantly different rules. Purchasers, on the other hand, face uncertainty in terms of protection when buying cross-border and via the Internet. In lieu of harmonizing steps, it must be hoped that information on pertinent warranty-law schemes spreads further. This article hopefully contributes to the movement towards sustainable production through its advocacy for implementing legal solutions to combat planned obsolescence. 